\title{
Ortaokul Yöneticilerinin Kuantum Liderlik Davranışları ile Öğretmenlerin İnisiyatif Alma Düzeyleri Arasındaki İlişkinin İncelenmesi*
}

\section{The Relationship Between Quantum Leadership Behaviors of Secondary School Principals and Teachers' Level of Taking Initiative}

\author{
Meltem Tufan, ${ }^{a}$ Mithat Korumaz ${ }^{\text {b,** }}$ \\ ${ }^{a}$ Matematik Öğretmeni, Soğanlık Şehit Oktay Karakelle İmam Hatip Ortaokulu, İstanbul/Türkiye. \\ ORCID: 0000-0002-3804-7571

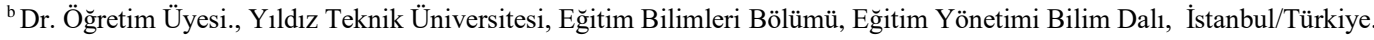 \\ ORCID: 0000-0002-2862-8380
}

\section{MAKALE BİLGISII}

Makale Geçmişi:

Başvuru tarihi: 05 Ekim 2019

Düzeltme tarihi: 16 Aralık 2019

Kabul tarihi: 02 Ocak 2020

\section{Anahtar Kelimeler:}

Kuantum fiziği

Kuantum liderlik

İnisiyatif alma

Liderlik

\section{A R TICLE INFO}

\section{Article history:}

Received 05 October 2019

Received in revised form 16 December 2019

Accepted 02 January 2020

\section{Keywords:}

Quantum physics

Quantum leadership

Taking initiative

Leadership
ÖZ

Araştırmanın amacı, öğretmen görüşlerine göre okul yöneticilerinin kuantum liderlik davranışları ile öğretmenlerin inisiyatif alma düzeyleri arasındaki ilişkiyi belirlemektir. Araştırma ilişkisel tarama deseninde betimsel bir çalışma olarak gerçekleştirilmiştir. Araştırmanın örneklemini, 2018-2019 eğitim-öğretim yılında İstanbul İli Kartal ilçesindeki resmi ortaokullarda görev yapan ve basit tesadüfî örnekleme yöntemi ile belirlenen 306 öğretmen oluşturmaktadır. Araştırmanın verileri "Okul Yöneticilerinin Kuantum Liderlik Davranışları Ölçeği” ve "Eğitim Örgütlerinde İnisiyatif Alma Davranışı Ölçeği" ile toplanmıştır. Veriler parametrik yöntemler ile analiz edilmiştir. Elde edilen bulgulara göre okul yöneticilerinin kuantum liderlik davranış düzeyinin öğretmenlerin inisiyatif alma davranış düzeyi ile pozitif yönde ilişkili olduğu görülmektedir. Araştırmadan elde edilen sonuçlar doğrultusunda hem politika yapıcı ve uygulayıcılara hem de diğer araştırmalara yönelik önerilerde bulunulmaktadır.

\section{A B S T R A C T}

The aim of the study is to determine the relationship between school administrators' quantum leadership behaviors and teachers' initiative taking according to teachers' opinions. The research was conducted in correlational design. The sample of the study consists of 306 teachers who work in secondary state schools in Kartal district of Istanbul in 2018-2019 academic years. The data of the study were collected with "Principals' Quantum Leadership Behaviors Scale" and "Taking Initiative in Educational Organizational Scale". The collected data were analyzed through parametric tests. The participants of the study were determined by simple random sampling. According to the findings, it is seen that the quantum leadership behavior level of school principals is positively correlated with teachers' taking initiative behavior. In line with the results of the research, suggestions are made for both policy makers and practitioners.

\section{Giriş}

19. yüzyılın sonlarına doğru fizik biliminde yaşanan gelişmelerin diğer disiplinleri olduğu gibi liderlik çalışmalarını da etkilediği söylenebilir. Bu yönelim ile beraber tek doğrulu bir dünyadan rasyonel aklın temel alındığı pozitivist bir düşünme biçimine geçiş yaşanmıştır. Max Planck'ın öncülüğü ile başlayıp temelleri atılan kuantum fiziği ile önemli bir değişimin kapıları açılmıştır. $\mathrm{Bu}$ değişime paralel olarak ortaya çıkan modern liderlik

*Bu çalışma Meltem Tufan’ın, Dr. Öğr. Üyesi Mithat Korumaz danışmanlığında 2019 yılında, Yıldız Teknik Üniversitesi, Eğitim Bilimleri Anabilim Dalı, Eğitim Yönetimi Bilim Dalında tamamladığı "Okul Yöneticilerinin Kuantum Liderlik Davranışları ile Öğretmenlerin İnisiyatif Alma Düzeyleri Arasındaki İlișkinin İncelenmesi” başlıklı yüksek lisans tezinden üretilmiștir.

** Sorumlu yazar/Corresponding author

e-posta:mithatkorumaz@gmail.com 
kuramlarından biri de kuantum liderliktir. "Kuantum liderlik, kuantum fiziğinin varsayımlarına dayalı olarak açımlanan modern bir liderlik kuramıdır" (Erçetin, 2000). Fizik bilimi doğadaki enerji, madde ve hareket durumlarını açıklarken benzer şekilde liderlik de insan dinamiğini ve potansiyelini nasıl açığa çıkarılabileceği ile ilgilenmektedir. Liderlik teorileri ise insanın içindeki dinamikleri ortaya çıkarması bağlamında fizik bilimi ile benzerlik göstermektedir (Turan, 2017). Zohar' a (2018) göre yönetim biliminin fizik biliminden etkilenmesi yeni bir durum değildir. $\mathrm{Bu}$ bağlamda geleneksel liderlik kuramları özellikler teorisi, davranışçı yaklaşımlar durumsal yaklaşımlar Newton fiziğinin varsayımlarına dayanmaktadır.

20. yüzyılda bilim dünyasında meydana gelen gelişmeler hâkim dünya görüşünün temelini kökten sarsıp yeni bir paradigmanın gerekliliğinin ortaya koymuştur. Bu durum yeni kavramları anlamanın zorluğu açısından geçmişteki bilimsel devrimlerden farklı olarak yorumlanmaktadır (Capra, 2012). Zohar (2018), önceki paradigma dönüşümlerini oda içindeki eşyaların yerlerini değiştirmek olarak açıklarken kuantum çağı ile yaşanan paradigma değişimini eşyaları değiştirmek olarak açıklamaktadır. Kuhn (2018) ise bu durumu eskiden bakılan tüm nesnelerin aynı olduğu bilindiği halde onlara bambaşka bir mercek ile bakmak olarak yorumlamaktadır. Yeni bilim paradigması ile beraber liderlik alanında yapılan çalışmaların da yön değiştirdiği ifade edilebilir. Daha önceki değişimlerinde liderlik olgusuna yönetsel beceriler eklenirken, 20. yüzyılda meydana gelen dönüşüm ile beraber liderin, deterministik aklın bir ürünü olan davranış biçimlerinin, ortaya çıkan yeni durumlarda yeterli görülmemesi ve aynı zamanda liderliğin hâkim değerlerinin dönüşmesi, kuantum liderliğin halihazırda öneriyor olduğu becerilerin ön plana çıkmasını sağlamıştır (Şimşek ve Aytemiz 1997'den akt: Papatya ve Dulupçu, 2006).

Kuantum fiziği, evrenin yasalarına ve işleyişine yönelik hâkim olan paradigmanın sorgulanmasının yolunu açmıştır denebilir. Bu sorgulama aynı zamanda doğa bilimlerinin temel yasalarına öykünme özelliği gösteren yönetimin de içerisinde yer aldığı sosyal bilimler alanında da kendini göstermiştir. Kuantum yönetim tarzı, madde yerine enerji, oluş yerine gelişim, sebep yerine rastlantı, determinizm yerine yapısalcılık, örgütün yapısal ve işlevsel yanlarından çok örgütsel yaşamın ruhsal nitelikleri ve özelliklerini öne çıkarmıştır (Overman, 1996). Uzunçarşıll, Toprak ve Ersun (2000), kuantum liderliği; liderlik ilișkileri, liderlik etkisinin kaynağı ve belirsizlik olmak üzere üç boyutta açıklamışlardır. Shelton ve Darling (2001) kuantum fiziğinin varsayımlarına dayanarak kuantum görme, kuantum düşünme, kuantum hissetme, kuantum biliş, kuantum güvenme, kuantum davranış, kuantum oluş olmak üzere yedi beceri ortaya koymuşlardır. Fris ve Lazaridou (2006) ise kuantum liderliği (1) kendi kendini örgütleme eğilimi, (2) belirsizlik ve karmaşada çalışmak ve (3) kuantum paradigmasının temel zorunluluklarının vizyon ve değer olduğunu fark etme şeklinde üç boyutta açıklamıştır.

İnsan dinamiğinin Newton fiziğinin varsayımlarına dayalı diğer geleneksel liderlik teorilerinden (özellikler teorisi, davranış teorisi, durumsal yaklaşımlar) farklı olarak ortaya çıkarılmasını sağlayan eğitim örgütlerinde kuantum liderlik paradigması ise Erçetin (2000) tarafından açımlanmıştır.
Erçetin (2000), kuantum liderlik paradigmasının boyutlarını kuantum ve klasik fiziğin varsayımlarını karşılaştırarak ortaya koymuştur. $\mathrm{Bu}$ gruplandırmaya göre kuantum liderliğin ilk boyutu kuantum fiziğinin "dalga-parçacık ikililiği" varsayımına dayanmaktadır. Erçetin (2000) fotonun hem dalga hem parçacık özelliği göstermesini kuantum liderlik bağlamında liderliği, 'lider-izleyen ikileminde bir etkileşim alanı' olarak yorumlar. Eğitim örgütlerinde, okul yöneticileri ve öğretmenler bir maddenin dalgacık ve parça yönü olarak düşünülebilir. Bu bağlamda okullarda yönetici ve öğretmenler bütünleşerek oluşturdukları etkileşim alanından beslenmektedir (Konan, 2015). Erçetin (2000) kuantum liderliğin ikinci boyutunu, kuantum fiziğinin "belirsizlik ilkesine" dayanarak, 'liderliğin yapılandırılamaz ve kestirilemez' olduğu şeklinde ifade etmektedir. Bu boyuta göre kuantum liderler, bulundukları örgütün altyapılarını belirsizliklere karşı esnek davranmaya firsat verecek biçimde tasarlamalı ve belirsizlik karşısındaki olasılıkları görerek risk alabilmelidirler (Zohar, 2018). Erçetin' in (2000) kuantum liderlik paradigmasının üçüncü boyutu ise 'liderlik olgusunun kesikliğ $i^{\prime}$ şeklindedir. Bu boyut "ışı̆̆ı̆ kesikli hareket ettiği" varsayımına dayanmaktadır. Bu varsayıma göre, liderlik kişiden kişiye değişebilir, lider değişebilir ya da liderlik el değiştirebilir (Erçetin, 2000). Kuantum liderliğe ilişkin son boyut ise 'liderliğin etkisi, etkileşime dayalıdır' şeklindedir. Bu boyut kuantum fiziğinin "ancak belli bir yere kadar güç uygulanabileceği sonrasında ne kadar güç uygulanırsa uygulansın enerjinin arttırılamayacağ $\iota^{\prime \prime}$ varsayımına dayanmaktadır. Buna göre diğer liderlik yaklaşımlarından farklı olarak kuantum liderler, öngörülemezliğin temel varsayım olduğu, lider olarak okul yöneticisi ve öğretmenin bütünleşerek oluşturdukları etkileşim alanın görece önemi ve liderliğin süreklilik arz etmek yerine kesikli bir biçimde devam ettiği ön plana çıkarılmıştır. Liderliğe ilişkin geliştirilen bu yeni bakış açısının işgörenlerin başlatıcılık, öz yatırım ve basiret gösterme gibi inisiyatif almaya ilişkin alışkanlıklarını nasıl etkilediği oldukça önemli görülmektedir.

İnisiyatif alma davranışının en çok kabul gören tanımlarından biri bireyin inisiyatifi davranış düzeyinde göstermesine ilişkindir. Bu tanıma göre Frese ve diğerlerine (1996) göre inisiyatif alma davranışı örgüt çalışanlarının örgütsel ve bireysel hedeflere uygun şekilde resmi iş tanımlarından fazlasını kendiliğinden yapmasıyla ortaya çıkmaktadır. Bu bağlamda inisiyatif alma davranışını 5 boyutta açıklanmaktadır. Bu boyutlar, örgüt amaçlarına bağlı kalmak, uzun dönem odaklanmak, eylem odaklı ve amaca yönelik olmak, engel, sorun ve tersliklere karşı dirençli olmak ve kendi kendine başlatıcı ve proaktif yaklaşım sergilemek olarak sıralanabilir.

Sonraki araştırmalar ile beraber inisiyatif alma davranışı, kendiliğinden başlatmak, proaktif olmak (geleceği öngörebilme, basiretli olma) ve engellerin üstesinden gelmede israr etmek olmak üzere üç boyuta indirgenmiştir (Frese \& Fay, 2001; Frese \& Fay, 2002; Frese, vd., 1997; Frese, vd., 1996). Buna göre inisiyatif alma davranışını tanımlamak gerekirse; bireylerin bir işi ya da yeniliği aktif ve kendiliğinden başlatabilmesi, kendisinden beklenen rolün ötesine geçerek önüne çıkan engelleri aşmak konusunda 1srarc1 olması, problemin oluşmasına izin vermeden önlenmesi anlamına gelen bir iş davranışıdır (Frese \& Fay, 2001; Speier \& Frese, 1997). Çakmak ve diğerleri (2015) ise söz konusu üç boyutun yanında Frese \& Fay'ın (2002) 
çalışmasına dayanarak öz-yatırım boyutunun da göz önünde bulundurulması gerektiğini ifade etmişlerdir. Çünkü kendiliğinden başlama, proaktif yaklaşım ve gelecekteki sorunlara çözüm bulma arzusu yüksek düzeyde öz-yatırım davranışı gerektirmektedir. Öz-yatırım bireyin kariyer hedeflerine ulaşması adına kendine yaptığı yatırımlar olarak tanımlanmaktadır. Frese ve Fay'a (2002) göre geleceği öngörebilme, rolünün gerektirdiklerinin ötesinde amaçların geliștirilmesini daha olası hale getirdiği için bu duruş bireyi kendiliğinden amaçlar geliştirmeye yöneltmektedir. $\mathrm{Bu}$ amaçlar engellerin üzerinde gelme ihtiyacını da ortaya çıkarır. Engelleri aşma isteği bireyi bir işi kendiliğinden başlatmaya sürükleyebilmektedir. Kendiliğinden bașlatma bireyin potansiyel geleceğe bakmasına ve bu nedenle de yüksek düzeyde öz-yatırım davranışı göstermesine neden olmaktadır.

İnisiyatif alma davranışının ilk boyutu olan Başlatıcılık (selfstarting), bireyin talimat almaksızın ya da rolünün gerekliliği olmaksızın veya söylenmeden bir şeyi yapmasıdır (Frese \& Fay, 2001; Frese \& Fay, 2002). Bu bağlamda birey, örgütün belirlediği amaçlardan çok kariyer hedeflerine dönük olarak kendi amaçlarını belirlemektedir (Frese, vd., 2007). Basiret gösterme (proactivity) geri bildirimde bulunmayı, gelecekteki problem sinyallerini fark edip ortaya çıkmadan üstesinden gelmeyi ifade etmektedir. Proaktif çalışanlar, geleceğin ihtiyaçlarına dönük şekilde iş çevrelerini değiştirme gayreti gösterirler (Frese \& Fay, 2001; Frese \& Fay, 2002). Engelleri aşma (overcome barriers); amaca ulaşmak için çaba sarf etme, kararlılık gösterme ve 1srar etmeyi içermektedir (Frese, vd., 1996). Bu yönü ile inisiyatif, harcanan zamanı ve deneme sayısını önemsemeden yeni yöntemlerle örgütsel ve bireysel kariyer hedeflere ulaşmayı içermektedir (Frese, vd., 1997). Son olarak diğer üç boyut ile ilişkili olabileceği düşünülen öz yatırım boyutu (selfinvestment) kişilerin hem bireysel kariyer hedeflerini gerçekleştireceklerine olan inanç karşısında eyleme geçmesini hem de örgütsel verimliliğe katkısını artırmak için kendisini geliştirmesini ifade etmektedir. Buna ilişkin birey inisiyatif alarak kariyer planı oluşturur ve buna paralel olarak gelişimine katkı sağlayacak eylemlerde bulunabilir (Çakmak, vd., 2015). İnisiyatif alma davranışı genelde kâr amacı güden örgütler için araştırma konusu olmuştur (Redfern, vd., 2010). Ancak son yıllarda yapılan çalışmalar (Akın ve Anlı, 2011; Akın, 2014; Çakmak, vd., 2015; Taşkın, 2016) kar amacı gütmeyen eğitim örgütlerinde inisiyatif alma konusunun öneminin giderek artığını göstermektedir.

21. yüzyılda okul yönetiminde etkili liderlik kavramının önemi anlaşılmıştır. $\mathrm{Bu}$ bağlamda liderin niteliklerinin eğitim ve öğretim çıktılarında önemli fark oluşturduğu; etkili yönetim ve liderlik uygulamalarının, eğitim örgütlerinin amaçlarına ulaşmada önemli bir rol oynadı̆̆ı; hızla büyüyen ve küreselleşen ekonomi dünyasında eğitilmiş iş gücünün sürekli bir rekabet ortamında bulunduğu ve okulların hızla değişen ve küreselleşen iş dünyasına uygun bireyler yetiştirmesi gerektiği gibi varsayımların gün geçtikçe güçlendiğini söylemek mümkündür. $\mathrm{Bu}$ bağlamda okul yönetiminde liderlik davranışının ne olması gerektiği yılların öne çıkan tartışmalarından biri halini almıştır (Bush, 2008; Erçetin, 2001; Turan, 2017; Yaşar-Kip, 2014).

Garmston ve Wellman (1995), atom altı dünyasındaki paradoksların sosyal sistemlerde de bulunduğunu ortaya koymaktadır. Buna göre eğitim liderleri kontrol ve denetim odaklı olmaktan ziyade akışı ve enerji değişimlerini dikkate alırlar. Düzene ulaşma, odaklanma, enerji alanlarını geliştirme bilgiyi ve etkileşimi arttırmak kuantum okul liderlerinin görevlerindendir. Wheatley (2006) ise kuantum liderlik özellikleri gösteren okul yöneticilerinin enerji akışına odaklanarak, enerjinin doğru ve faydalı şekilde kullanılmasını sağladıklarını ve bu şekilde okulun amaçlarına ulaşmasını kolaylaştırdıklarını ifade etmektedir.

İnisiyatif alabilme ve inisiyatif aldırmaya teşvik etme, liderlere atfedilen bir özelliktir (Stodgill, 1948; Stodgill, 1974). Bu durum farklı liderlik türleri bakımından araştırma konusu edilmiştir. Örneğin, Bass (1990), modern liderlik kuramlarından olan karizmatik liderliğin etkisinin inisiyatif alma davranışı ile artacağını belirterek, liderlik ile inisiyatif alma davranışını bağdaştırmaktadır (Frese \& Fay, 2002). Benzer şekilde dönüşümcü liderlik davranışları da inisiyatif alma davranışını gerektirdiği varsayılmaktadır (Bass \& Avalio, 1990). Literatürde kuantum liderlik ile inisiyatif alma davranışını aynı anda konu edinen bir çalışmaya rastlanılmamıştır. Bu nedenle bu araştırmanın amacı okul yöneticilerinin kuantum liderlik davranışları ile öğretmenlerin inisiyatif alma düzeyleri arasında ilişkinin incelenmesidir. Araştırma kapsamında yanıtı aranan sorular ise şu şekildedir:

1. Öğretmenlerin görüşlerine göre okul yöneticilerinin kuantum liderlik davranışlarını gösterme ve öğretmenlerin inisiyatif alma davranışları hangi düzeydedir?

2. Öğretmenlerin okul yöneticilerinin kuantum liderlik davranışlarını gösterme düzeylerine ve öğretmenlerin inisiyatif alma davranışına ilişkin görüşleri öğretmenlerin kariyer evresi ve müdür ile çalışma süresi değişkenlerine göre anlamlı düzeyde farklılaşmakta mıdır?

3. Öğretmenlerin görüşlerine göre okul yöneticilerinin kuantum liderlik davranışlarını gösterme düzeyi ile öğretmenlerin inisiyatif alma davranışını gösterme düzeyi arasında anlamlı bir ilişki var mıdır?

\section{Yöntem}

Bu kısımda araștırmanın deseni, evren-örneklemi, veri toplama araçları, veri toplama süreci ve veri analizi başlıklarına yer verilmiştir.

\subsection{Araştırmanın Deseni}

$\mathrm{Bu}$ araştırmada, öğretmen görüşlerine dayalı okul yöneticilerinin kuantum liderlik davranışları ile inisiyatif alma davranışı düzeyi arasındaki ilişkinin belirlenmesi amaçlandığından, araştırma ilişkisel tarama deseninde göre tasarlanmıştır. İlişkisel tarama deseni iki ya da daha fazla değişken arasında birlikte değişimin olup olmadığını ve bu değişimin düzeyini belirlemeyi amaçlayan araştırma desenidir (Karasar, 2013). İlişkisel tarama deseninin özelliklerine uygun olarak araştırma kapsamında sadece değişkenler arasındaki ilişki incelenmiştir.

\subsection{Araştırma Evreni ve Örneklemi}

Araştırmanın evreni, 2018-2019 eğitim-öğretim yılında İstanbul İli Kartal ilçesinde bulunan resmi ortaokul kurumlarında görevli öğretmenlerden oluşmaktadır. Çalışma 
evreni Kartal ilçesinde bulunan 24 resmi ortaokulda görev yapan toplam 1171 öğretmenden oluşmaktadır. Araştırmanın örneklemi basit tesadüfî örnekleme yöntemi ile belirlenmiştir. Örneklem olarak ulaşılması gereken eleman sayısı Yamane’nin (2006) önerdiği \%95 güven aralığına göre $\left(\mathrm{p}=0.5^{\mathrm{a}}\right) 286$ olarak hesap edilmiştir. Buna uygun olarak çalışmada 306 katılımcı araştırmaya katılmıştır.

Tablo 1. Araştırmaya Katılan Öğretmenlere Yönelik Yüzde ve Frekans Değerleri

\begin{tabular}{|c|c|c|c|}
\hline $\begin{array}{l}\text { Demografik } \\
\text { Özellikler }\end{array}$ & Kategori & $\begin{array}{l}\text { Frekans } \\
(N)\end{array}$ & $\begin{array}{l}\text { Yüzde } \\
(f)\end{array}$ \\
\hline \multirow[t]{2}{*}{ Cinsiyet } & Kadın & 214 & 69,9 \\
\hline & Erkek & 92 & 30,1 \\
\hline \multirow[t]{5}{*}{ Kariyer Evresi } & Kariyere Giriş & 61 & 19,9 \\
\hline & Durulma & 109 & 35,6 \\
\hline & Deneycilik & 59 & 19,3 \\
\hline & Uzmanlık & 44 & 14,4 \\
\hline & Sakinlik & 33 & 10,8 \\
\hline \multirow[t]{2}{*}{ Eğitim Durumu } & Lisans & 268 & 87,6 \\
\hline & $\begin{array}{l}\text { Yüksek Lisans } \\
\text { Yüksek Lisans }\end{array}$ & 38 & 12,4 \\
\hline \multicolumn{2}{|c|}{$\begin{array}{l}\text { Aynı Okulda Çalışma 1-5 Yıl } \\
\text { Süresi }\end{array}$} & 199 & 65,0 \\
\hline & 6-10 Y1l & 74 & 24,2 \\
\hline & $11-15 Y_{11}$ & 18 & 5,9 \\
\hline & 16 Y1l ve Üzeri & 15 & 4,9 \\
\hline \multicolumn{2}{|c|}{$\begin{array}{l}\text { Mevcut Okul Müdürü 1-2 Yil } \\
\text { ile Calıșma Süresi }\end{array}$} & 147 & 48,0 \\
\hline & 3-4 Y1l & 150 & 49,0 \\
\hline & 5 Y1l ve Üzeri & 9 & 3 \\
\hline
\end{tabular}

Araştırmaya evrende yer alan 24 resmi ortaokulda görev yapan 306 öğretmenin \%69,9'u kadın, \%30,1'i erkektir. Öğretmenlerin kariyer evreleri Bakioğlu'nun (1996) önerdiğgi kariyer evrelerine uygun olarak belirlenmiştir. Mesleki kıdemi 1-5 yıl arası "kariyere giriş evresi", 6-10 yıl arası "durulma", 11-15 y1l arası "deneycilik", 16-20 y1l aras1 "uzmanlık" ve 21 y1l ve üzeri olanlar ise "sakinlik" evresi olarak tanımlanmaktadır. Buna göre araştırmaya katılan öğretmenlerin \% 19,9'u kariyere giriş evresinde (1-5 yıl aras1), \%35,6's1 durulma evresinde (6-10 y1l aras1), \%19,3'ü deneycilik evresinde (11-15 yıl arası), \% 14,4'ü uzmanlık evresi (16-20 y1l arasi) ve \%10,8'i durulma evresinde (21 yıl ve üzeri) bulunmaktadırlar. Öğretmenler eğitim durumlarına göre incelendiğinde \%87,6's1 lisans ve \% 12,4'ü yüksek lisans mezunudur. Öğretmenlerin \%65,0'1 1-5 y1l arası aynı okulda çalışmakta, \% 24,2'si 6-10 yıl arası aynı okulda çalışmakta, \%5,9'u 11-15 yıl arası aynı okulda ve \%4,5'i 16 yıl ve daha fazla aynı okulda çalışmaktadır. Öğretmenlerin $\%$ 48.00 1 mevcut müdürle 1-2 y1l aras1, \%49,0'1 3-4 yıl aras1 ve sadece \% 3 'ü 5 yıldan fazla birlikte çalışmaktadırlar.

\subsection{Veri Toplama Araçları}

$\mathrm{Bu}$ araştırmada veri toplamak amaciyla "Okul Yöneticilerinin Kuantum Liderlik Davranışları Ölçeği” ve "Eğitim Örgütlerinde İnisiyatif Alma Davranışı Ölçeği" olmak üzere iki ölçme aracı bir arada kullanılmıştır.

\section{Okul yöneticilerinin kuantum liderlik davranışları ölçeği}

Araştırmada okul müdürlerinin kuantum liderlik davranışlarını gösterme düzeylerini belirlemek amacıyla Erçetin ve diğerleri (2016) tarafindan geliştirilen "Okul Yöneticilerinin Kuantum Liderlik Davranışları Ölçeği”" kullanılmıştır. Bu bağlamda öncelikle ölçeğin kullanım izni alınmıştır. Ölçeği geliştiren araştırmacılar tarafından yapılan Açımlayıcı Faktör Analizi (AFA) sonucuna göre ölçek; "liderlik, lider-izleyenler ikileminde bir etkileşim alanıdır", "liderlik yapılandırılamaz ve kestirilemez", "liderlik olgusunun kesikliliği" ve "liderliğin etkisi etkileşime dayalıdır" olmak üzere 4 boyuttan ve toplam 38 maddeden oluştuğu sonucuna ulaşılmıştır. Çalışmanın verilerine göre Okul Yöneticilerinin Kuantum Liderlik Davranışları Ölçeğinin Cronbach Alfa iç tutarlık katsayısı "Liderlik, Lider-İzleyenler İkileminde Bir Etkileşim Alanıdır" $\alpha=0.95$, "Liderlik Yapılandirılamaz ve Kestirilemez" alt boyutunda $\alpha=0.95$, "Liderlik Olgusunun Kesikliliği" alt boyutunda $\alpha=$ 0.94 ve"liderliğin etkisi etkileşime dayalıdır" alt boyutunda ise $\alpha=0.92$ ve ölçeğin tamamına ilişkin $\alpha=0.98$ değeri ile ölçeğin yüksek düzeyde güvenilir olduğu söylenebilir. Ayrıca ölçeğin toplam puanın 1'e yaklaşması iç tutarlılığının yüksek olduğu göstermektedir.

\section{Eğitim örgütlerinde inisiyatif alma davranışı ölçeği}

Öğretmenlerin inisiyatif alma davranış düzeylerini belirlemek amacı ile Çakmak, Gündüz ve Korumaz (2015) tarafından geliştirilen dört boyutlu Eğitim Örgütlerinde İnisiyatif Alma Ölçeği kullanılmıştır. Bu çerçevede önce ölçeğin kullanım izni alınmıştır. Araştırmacılar tarafından yapılan istatistikî sınamalar, alan yazın ve uzman görüşlerin doğrultusunda son şekli verilen "başlatıcılık", "engelleri aşma", "basiret gösterme" ve "öz yatırım" boyutlarından oluşan eğitim örgütlerinde kullanılabilecek 35 maddelik bir ölçektir. Bu çalışmanın verilerine göre öğretmenlerin İnisiyatif Alma Davranışları Ölçeğinin Cronbach Alfa iç tutarlık katsayısı Öz-Yatırım alt boyutunda $\alpha=0.60$, Başlatıcılık alt boyutunda $\alpha=0.66$, Basiret alt boyutunda $\alpha=$ 0.87 ve Engelleri Aşma alt boyutunda ise $\alpha=0.92$ ve ölçeğin tamamına ilişkin $\alpha=0.89^{\prime}$ 'dir. Ölçeğin iç tutarlılık katsayıları değerlendirildiğinde Öz Yatırım ve Başlatıcılık alt boyutlarının orta düzeyde ve Basiret ve Engelleri Aşma alt boyutlarında yüksek düzeyde güvenilirdir. Ölçeğin toplam puanına ilişkin iç tutarlılığının yüksek olduğu söylenebilir.

\subsection{Veri Toplama Süreci}

Kartal ilçesinde yer alan resmi ortaokul kurumlarında görevli öğretmenlere yönelik veri toplama araçları, 2018-2019 eğitim-öğretim yılı Aralık ayında araştırmacılar tarafından bizzat okullara gidilerek uygulanmıştır. Sonuç olarak belirlenen örneklem üzerinden 339 katılımcıya ulaşılmıştır. Ulaşılan 339 örneklemden 21 tanesi okul müdürü ile çalışma sürelerinin 1 yıldan az olması sebebi ile 12 tanesi ise özenli doldurulmadığı düşünüldüğünden (aynı maddeye birden fazla yanıt verilmesi, tüm maddelere aynı yanıtın verilmesi, 
demografik özelliklerin boş bırakılması vb.) çıkarılmıştır. Geriye kalan 306 ölçek değerlendirmeye alınmıştır.

\subsection{Verilerin Analizi}

Araştırma verileri SPSS 20,0 paket programı ile analiz edilmiştir. Verilerin normal dağılıp dağılmadığını ölçmek için Skewness ve Kurtosis normallik testlerinde faydalanılmıştır. Skewness değeri -0.70 ve Kurtosis değeri ise 0,18 arasında değere sahiptir. Kurtosis ve Skewness değerleri -2 ile +2 arasında olması normal dağılım olduğu göstermektedir (Tabachnick \& Fidell, 2013). Bunun yanı sıra yapılan Kolmogrow Smirnow testi 0.05 düzeyinde verilerin dağılımın normal olduğunu göstermiştir. Buna göre araştırmanın verileri parametrik yöntemler ile analiz edilmiştir. Araştırmanın alt amaçları doğrultusunda farklılığın sınanması için ilişkisiz örneklem $t$-testi ve tek yönlü varyans analizi tesleri kullanılmıştır. Tek yönlü varyans analizlerinde varyansları homojen olan gruplarda yaygın olarak kullanılan LSD çoklu karşılaştırma testi tercih edilmiştir. LSD testi grupların farklı örneklem sayısına sahip olması ve ayrıca bu testin $\alpha$ hata payını kontrol altında tutma özelliğinden dolayı tercih edilmiş ve anlamlılık düzeyi $\mathrm{p}<0.05$ olarak kabul edilmiştir. Öğretmen görüşlerine göre okul yöneticilerinin kuantum liderlik davranışlarının, öğretmenlerin inisiyatif alma davranışlarıyla ilişkisi Pearson Korelasyon Analizi ile test edilmiştir.

\section{Bulgular}

Araştırma kapsamında bulgular araştırma sorularına uygun sırasıyla sunulmuştur. Ancak genel betimsel değerlerin görülebilmesi için ilk olarak okul müdürlerinin kuantum liderlik davranışlarını gösterme ve öğretmenlerin inisiyatif alma düzeylerine ilişkin betimsel değerler sunulmuştur.
Tablo 2. Kuantum liderlik ve inisiyatif alma betimsel değerleri

\begin{tabular}{|c|c|c|c|c|c|c|}
\hline Ölçek & Alt Boyutlar & En & En & $\overline{\mathrm{X}}$ & $S S$ & Sh_ \\
\hline \multirow{4}{*}{ 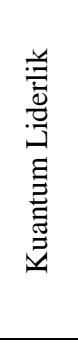 } & $\begin{array}{l}\text { Liderlik, Lider-İzleyenler } \\
\text { İkileminde Bir Etkileșim }\end{array}$ & 1 & 5 & 3,86 & 0,87 & 0,05 \\
\hline & $\begin{array}{l}\text { Liderlik Yapılandırılamaz } \\
\text { ve Kestirilemez }\end{array}$ & 1 & 5 & 3,52 & 0,89 & 0,05 \\
\hline & $\begin{array}{l}\text { Liderlik Olgusunun } \\
\text { Kesikliliğ̣i }\end{array}$ & 1 & 5 & 3,71 & 0,89 & 0,05 \\
\hline & $\begin{array}{l}\text { Liderliğin Etkisi Etkileşime } \\
\text { Davalıdır }\end{array}$ & 1 & 5 & 3,65 & 0,81 & 0,05 \\
\hline \multirow{4}{*}{ 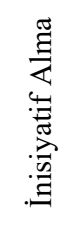 } & Öz-yatırım & 1 & 5 & 3,83 & 0,59 & 0,03 \\
\hline & Başlatıcılık & 1 & 5 & 3,26 & 0,42 & 0,02 \\
\hline & Basiret & 1 & 5 & 3,65 & 0,51 & 0,03 \\
\hline & Engelleri aşma & 1 & 5 & 4,66 & 0,63 & 0,04 \\
\hline
\end{tabular}

Tablo 2 incelendiğinde, okul yöneticilerinin kuantum liderlik davranışlarına ilişkin öğretmen görüşlerinin ortalama değeri $\bar{x}=3.68$, standart sapması ise $0,82^{\prime}$ dir. "Liderlik, lider-izleyenler ikileminde bir etkileşim alanıdır" alt boyutuna ilişkin öğretmen görüşlerinin ortalama değeri $\bar{x}=3,86$, standart sapması ise $0,87^{\prime}$ dir. "Liderlik yapılandırılamaz ve kestirilemez" alt boyutuna ilişkin öğretmen görüşlerinin ortalama değeri $\bar{x}=3,52$ ve standart sapması ise 0,89 'dur. "Liderlik olgusunun kesikliliği" alt boyutuna ilişkin öğretmen görüşlerinin ortalama değeri $\bar{x}=3,71$ ve standart değeri ise 0,89 'dur. "Liderliğin etkisi etkileşime dayalıdır" alt boyutuna ilişkin öğretmen görüşlerinin ortalama değeri $\bar{x}=3,65$ ve standart sapması 0,81 'dir. Öğretmenlerin inisiyatif alma davranışlarına ilişkin görüşlerin betimsel istatistiklerine bakıldığında ortalama değerinin $\overline{\mathrm{X}}=3.86$, standart sapma değeri ise $0,02^{\prime}$ dir. Eğitim Örgütlerinde İnisiyatif alma ölçeğinin ilk alt boyutu olan "öz-yatırım" boyutuna ilişkin öğretmen görüşlerinin ortalama değeri $\bar{x}=3,83$, standart sapma değeri ise 0,59 'dur. "Başlatıcılık" alt boyutuna ilişkin öğretmen görüşlerinin aritmetik ortalama değeri ise $\bar{x}=3,26$ ve standart değeri 0,42 'dir. "Basiret" alt boyutuna ilişkin öğretmen görüşlerinin aritmetik ortalama değeri ise $\bar{x}=3,65$ ve standart değeri 0,51 'dir. Son olarak "engelleri aşma" alt boyutuna ilişkin öğretmen görüşlerinin aritmetik ortalama değeri ise $\bar{x}=4,66$ ve standart değeri 0,63 'tür.

Öğretmenlerin okul yöneticilerinin kuantum liderlik davranışlarını gösterme düzeylerine ve öğretmenlerin inisiyatif almalarına ilişkin görüşleri kariyer evresi değişkenine göre farklılaşıp farklılaşmadığı incelenmiştir. Bu kapsamda öğretmen kariyer evreleri; kariyere giriş evresi (1-5 y1l), durulma evresi (6-10 y1l), deneycilik evresi (11-15 y1l), uzmanlık evresi (16-20 y1l) ve sakinlik evresi (21 ve üzeri yıl) olmak üzere 5 evreye ayrılmaktadır (Bakioğlu, 1996). Bu kapsamda öğretmen görüşlerinin kariyer evresi değişkenine göre görüşleri farklılaşıp farklılaşmadığı tek yönlü varyans analizi ile sınanmıştır. 
Tablo 3. Öğretmenlerin okul yöneticilerinin kuantum liderlik davranışlarına ilişkin göüşlerinin kariyer evresi değişkenine göre farklılaşma düzeyi

\begin{tabular}{|c|c|c|c|c|c|c|c|c|c|c|c|}
\hline \multirow[b]{2}{*}{ Puan } & \multirow[b]{2}{*}{ Kariyer Evresi } & \multicolumn{4}{|c|}{$f \quad \overline{\mathrm{x}}$ ve $s s_{\text {Değerleri }}$} & & \multicolumn{5}{|c|}{ ANOVA Sonuçlart } \\
\hline & & $\mathrm{N}$ & $\overline{\mathrm{X}}$ & Ss & $\mathrm{Sh}_{\overline{\bar{x}}}$ & Var. K. & $K T$ & $s d$ & KO & $F$ & $P$ \\
\hline \multirow{6}{*}{ 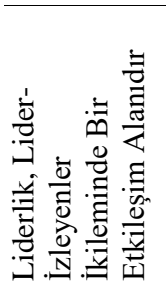 } & Kariyere Giriş & 61 & 36,52 & 6,87 & 0,88 & G. Aras1 & 445,91 & 4 & 111,48 & 1,83 & 0,12 \\
\hline & Durulma & 109 & 35,11 & 7,63 & 0,73 & G. İçi & 18295,62 & 301 & 60,78 & & \\
\hline & Deneycilik & 59 & 33,49 & 8,50 & 1,11 & Toplam & 18741,53 & 305 & & & \\
\hline & Uzmanlık & 44 & 32,93 & 8,15 & 1,23 & & & & & & \\
\hline & Sakinlik & 33 & 34,55 & 8,16 & 1,42 & & & & & & \\
\hline & Toplam & 306 & 34,71 & 7,84 & 0,45 & & & & & & \\
\hline \multirow{6}{*}{ 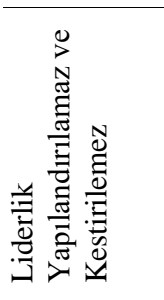 } & Kariyere Giriş & 61 & 33,36 & 6,60 & 0,84 & G. Aras1 & 556,07 & 4 & 139,02 & 2,20 & 0,07 \\
\hline & Durulma & 109 & 32,36 & 7,80 & 0,75 & G. İçi & 18999,21 & 301 & 63,12 & & \\
\hline & Deneycilik & 59 & 30,34 & 8,39 & 1,09 & Toplam & 19555,28 & 305 & & & \\
\hline & Uzmanlık & 44 & 29,41 & 9,29 & 1,40 & & & & & & \\
\hline & Sakinlik & 33 & 31,52 & 7,95 & 1,38 & & & & & & \\
\hline & Toplam & 306 & 31,65 & 8,01 & 0,46 & & & & & & \\
\hline \multirow{6}{*}{ 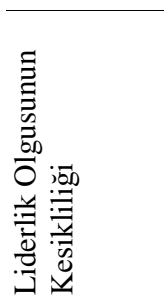 } & Kariyere Giriş & 61 & 37,70 & 7,75 & 0,99 & G. Aras1 & 444,56 & 4 & 111,14 & 1,41 & 0,23 \\
\hline & Durulma & 109 & 38,39 & 8,78 & 0,84 & G. İçi & 23762,88 & 301 & 78,95 & & \\
\hline & Deneycilik & 59 & 35,83 & 9,14 & 1,19 & Toplam & 24207,44 & 305 & & & \\
\hline & Uzmanlık & 44 & 35,39 & 9,97 & 1,50 & & & & & & \\
\hline & Sakinlik & 33 & 36,36 & 9,22 & 1,60 & & & & & & \\
\hline & Toplam & 306 & 37,11 & 8,91 & 0,51 & & & & & & \\
\hline \multirow{6}{*}{ 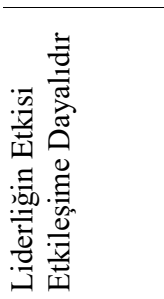 } & Kariyere Giriş & 61 & 38,00 & 6,91 & 0,88 & G. Aras1 & 627,37 & 4 & 156,84 & 2,42 & 0,05 \\
\hline & Durulma & 109 & 37,62 & 7,75 & 0,74 & G. İçi & 19477,08 & 301 & 64,71 & & \\
\hline & Deneycilik & 59 & 34,98 & 8,64 & 1,13 & Toplam & 20104,45 & 305 & & & \\
\hline & Uzmanlık & 44 & 34,68 & 9,24 & 1,39 & & & & & & \\
\hline & Sakinlik & 33 & 35,03 & 8,16 & 1,42 & & & & & & \\
\hline & Toplam & 306 & 36,49 & 8,12 & 0,46 & & & & & & \\
\hline
\end{tabular}

Tablo 3'de görülebileceği gibi, okul yöneticilerinin kuantum liderlik davranışları ölçeğinin alt boyutları puanlarının, öğretmenlerin kariyer evreleri değişkenine göre yapılan tek yönlü varyans analizi sonucunda "liderlik, lider-izleyenler ikileminde bir etkileşim alanıdır" alt boyutunda $\left(\mathrm{F}_{(12-293)}=1.83 ; \mathrm{p}>0.05\right)$, "liderlik olgusunun kesikliliği" alt boyutunda $\left(\mathrm{F}_{(12-293)}=1.41 ; \mathrm{p}>0.05\right)$, "liderlik yapılandırılamaz ve kestirilemez" $\left(\mathrm{F}_{(12-293)}=2.20 ; \mathrm{p}>0.05\right)$ aritmetik ortalamaları arasında anlamlı bir farklılık olmamasına karşın, "liderliğin etkisi etkileşime dayalıdır" alt boyutunda istatistiksel olarak anlamlı bir farkl111k $\left(\mathrm{F}_{(12-}\right.$ $\left.{ }_{293)}=2.42 ; \mathrm{p}<0.05\right)$ olduğu sonucuna ulaşılmıştır. Söz konusu farklılığın hangi gruplardan kaynaklandığını belirlemek üzere tamamlayıcı LSD post-hoc analizi yapılmıştır.
Liderliği Etkisi Etkileşime Dayalıdır alt boyutunda kariyere giriş evresinde olan öğretmenler $(\bar{x}=38,00)$ ile Deneycilik $(\bar{x}=34,98)$ ve uzmanlık evresinde olan öğretmenlerin aritmetik ortalamaları $\operatorname{arasında}(\bar{x}=34,68)$ anlamlı bir farklılık olduğu sonucuna ulaşılmıştır. Ayrıca durulma evresinde olan öğretmenler $(\bar{x}=37,62)$ ile deneycilik evresinde $(\bar{x}=34,98)$ ve uzmanlik evresinde olan öğretmenlerin artitmetik ortalamaları $(\bar{x}=34,68)$ arasında anlamlı bir farklılık bulunmuștur. Öğretmenlerin inisiyatif alma davranışını gösterme düzeyine ilişkin görüşlerinin kariyer evresi değişkenine göre farklılaşıp farklılaşmadığ 1 incelemek üzere yapılan tek yönlü varyans analizi sonuçları aşağıda yer almaktadır. 
Tablo 4.Öğretmenlerin inisiyatif alma davranışını kariyer evresi değişkenine göre farklılaşma düzeyi

\begin{tabular}{|c|c|c|c|c|c|c|c|c|c|c|c|}
\hline \multirow{2}{*}{ Puan } & \multirow{2}{*}{ Kariyer Evresi } & \multicolumn{4}{|c|}{$f \quad \overline{\mathrm{X}}$ ve $s S$ Değerleri } & \multicolumn{6}{|c|}{ ANOVA Sonuçları } \\
\hline & & $\mathrm{N}$ & $\overline{\mathrm{X}}$ & Ss & $\mathrm{Sh}_{\bar{v}}$ & Var. K. & $K T$ & $s d$ & $K O$ & 7 & $\mathrm{p}$ \\
\hline \multirow{6}{*}{ Öz yatırım } & Kariyere Giriş & 61 & 32,10 & 3,26 & 0,42 & G. Aras1 & 217,86 & 4 & 54,47 & 2,52 & 0,04 \\
\hline & Durulma & 109 & 30,73 & 4,66 & 0,45 & G. İçi & 6494,75 & 301 & 21,58 & & \\
\hline & Deneycilik & 59 & 30,44 & 5,53 & 0,72 & Toplam & 6712,61 & 305 & & & \\
\hline & Uzmanlık & 44 & 30,00 & 4,62 & 0,70 & & & & & & \\
\hline & Sakinlik & 33 & 29,21 & 5,07 & 0,88 & & & & & & \\
\hline & Toplam & 306 & 30,68 & 4,69 & 0,27 & & & & & & \\
\hline \multirow{6}{*}{ Başlatıcılık } & Kariyere Giriş & 61 & 25,54 & 3,57 & 0,46 & \multirow{6}{*}{$\begin{array}{l}\text { G. Arası } \\
\text { G. İçi } \\
\text { Toplam }\end{array}$} & 98,35 & 4 & 24,59 & \multirow[t]{6}{*}{2,22} & 0,07 \\
\hline & Durulma & 109 & 25,64 & 3,43 & 0,33 & & 3337,47 & 301 & 11,09 & & \\
\hline & Deneycilik & 59 & 26,61 & 3,09 & 0,40 & & 3435,82 & 305 & & & \\
\hline & Uzmanlık & 44 & 26,23 & 3,56 & 0,54 & & & & & & \\
\hline & Sakinlik & 33 & 27,21 & 2,55 & 0,44 & & & & & & \\
\hline & Toplam & 306 & 26,06 & 3,36 & 0,19 & & & & & & \\
\hline \multirow{6}{*}{ Basiret } & Kariyere Giriş & 61 & 37,34 & 5,52 & 0,71 & \multirow{6}{*}{$\begin{array}{l}\text { G. Arası } \\
\text { G. İçi } \\
\text { Toplam }\end{array}$} & 67,16 & 4 & 16,79 & \multirow[t]{6}{*}{0,65} & 0,63 \\
\hline & Durulma & 109 & 36,14 & 4,97 & 0,48 & & 7749,34 & 301 & 25,75 & & \\
\hline & Deneycilik & 59 & 36,27 & 4,29 & 0,56 & & 7816,50 & 305 & & & \\
\hline & Uzmanlık & 44 & 36,27 & 5,47 & 0,83 & & & & & & \\
\hline & Sakinlik & 33 & 36,85 & 5,29 & 0,92 & & & & & & \\
\hline & Toplam & 306 & 36,50 & 5,06 & 0,29 & & & & & & \\
\hline \multirow{6}{*}{ Engelleri aşma } & Kariyere Giriş & 61 & 42,20 & 5,89 & 0,75 & \multirow{6}{*}{$\begin{array}{l}\text { G. Arası } \\
\text { G. İçi } \\
\text { Toplam }\end{array}$} & 127,75 & 4 & 31,94 & \multirow[t]{6}{*}{1,00} & \multirow[t]{6}{*}{0,41} \\
\hline & Durulma & 109 & 41,50 & 5,33 & 0,51 & & 9576,14 & 301 & 31,81 & & \\
\hline & Deneycilik & 59 & 42,54 & 6,02 & 0,78 & & 9703,88 & 305 & & & \\
\hline & Uzmanlık & 44 & 41,18 & 5,92 & 0,89 & & & & & & \\
\hline & Sakinlik & 33 & 43,24 & 5,06 & 0,88 & & & & & & \\
\hline & Toplam & 306 & 41,98 & 5,64 & 0,32 & & & & & & \\
\hline
\end{tabular}

Tablo 4'te inisiyatif alma ölçeğinin alt boyutunun öğretmenlerin kariyer evresi değişkenine göre farklılaşıp farklılaşmadığını belirlemek üzere yapılan tek yönlü varyans analizi sonuçlarına göre "başlatıcılık" alt boyutu $\left(\mathrm{F}_{(4-301)}=2.22 ; \mathrm{p}>0.05\right)$, "basiret" $\left(\mathrm{F}_{(4-301)}=0.65 ; \mathrm{p}>0.05\right)$ ve "engelleri aşma" alt boyutlarında $\left(\mathrm{F}_{(4-301)}=1.00 ; \mathrm{p}>0.05\right)$ kariyer evresi değişkenine göre istatistiksel olarak anlamlı bir farklılık bulunmamaktadır. Öz yatırım alt boyutunda ise öğretmenlerin kariyer evresi değişkenine göre grupların aritmetik ortalamaları arasında anlamlı bir farklılık olmasına $\left(\mathrm{F}_{(4-301)}=2.52 ;<0.05\right)$ karşın, varyansların homojenliği testinde $\left(\mathrm{L}_{(4-301)}=4.59, \mathrm{p}<0.05\right)$ olduğundan dağılım normal dağılım göstermediğinden, yani varyans analizinin ön şartını sağlamadığından çoklu karşılaştırma testi yapılmamıştır. Öğretmenlerin görüşlerine göre okul yöneticilerinin kuantum liderlik davranışları ve öğretmenlerin inisiyatif alma davranışını gösterme düzeyine ilişkin görüşlerinin mevcut okul müdür ile çalışma süresi değişkenine göre farklılaşıp farklılaşmadığı incelenmiştir. Öğretmenlerin mevcut okul müdürleri ile çalışma süreleri "1-2 y1l, 3-4 yıl, 5 ve üzeri yıl" olarak sınıflandırılmıştır. Bu kapsamda öğretmenlerin mevcut okul müdür ile çalışma süresi değişkenine göre görüşlerinin farklılaşıp farklılaşmadığı tek yönlü varyans analizi ile sınanmıştır. 
Tablo 5. Öğretmenlerin okul yöneticilerinin kuantum liderlik davranışlarını gösterme düzeylerine ilişkin görüşlerinin mevcut müdür ile çalışma süresi değişkenine göre farklılaşma düzeyi

\begin{tabular}{|c|c|c|c|c|c|c|c|c|c|c|c|c|c|c|}
\hline \multirow{2}{*}{\multicolumn{4}{|c|}{ Puan }} & \multirow{2}{*}{$\begin{array}{l}\text { Okul Müdürüyle } \\
\text { Çalışma Süresi }\end{array}$} & \multicolumn{5}{|c|}{$f \overline{\mathrm{X}}_{\boldsymbol{v} e} S S$ Dě̆erleri } & \multicolumn{5}{|c|}{ ANOVA Sonuçları } \\
\hline & & & & & $\mathrm{N}$ & $\overline{\mathrm{X}}$ & Ss & $\mathrm{Sh}_{\bar{x}}$ & Var. K. & $K T$ & $s d$ & KO & $\boldsymbol{F}$ & $\boldsymbol{P}$ \\
\hline \multirow{4}{*}{\multicolumn{4}{|c|}{ 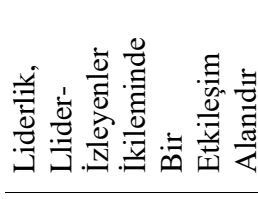 }} & 1-2 Y1l Arası & 147 & 35,14 & 7,34 & 0,61 & G. Aras1 & 252,53 & 2 & 126,26 & 2,07 & 0,13 \\
\hline & & & & 3-4 Y1l Aras1 & 150 & 34,03 & 8,35 & 0,68 & G. İçi & 18489,00 & 303 & 61,02 & & \\
\hline & & & & 5 Y1l ve Üzeri & 9 & 38,89 & 5,51 & 1,84 & Toplam & 18741,53 & 305 & & & \\
\hline & & & & Toplam & 306 & 34,71 & 7,84 & 0,45 & & & & & & \\
\hline \multirow{4}{*}{\multicolumn{4}{|c|}{ 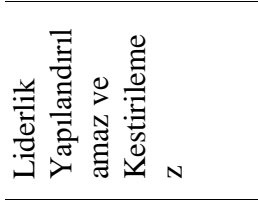 }} & 1-2 Y1l Aras1 & 147 & 32,38 & 7,53 & 0,62 & G. Aras1 & 379,45 & 2 & 189,73 & 3,00 & 0,05 \\
\hline & & & & 3-4 Y1l Aras1 & 150 & 30,69 & 8,43 & 0,69 & G. İçi & 19175,83 & 303 & 63,29 & & \\
\hline & & & & 5 Y1l ve Üzeri & 9 & 35,89 & 6,23 & 2,08 & Toplam & 19555,28 & 305 & & & \\
\hline & & & & Toplam & 306 & 31,65 & 8,01 & 0,46 & & & & & & \\
\hline \multirow{4}{*}{ 光 } & \multirow{4}{*}{ 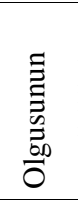 } & \multirow{4}{*}{\multicolumn{2}{|c|}{ 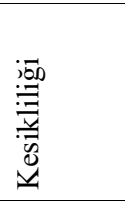 }} & 1-2 Y11 Aras1 & 147 & 37,60 & 8,19 & 0,68 & G. Aras1 & 267,23 & 2 & 133,61 & 1,69 & 0,19 \\
\hline & & & & 3-4 Y1l Aras1 & 150 & 36,38 & 9,60 & 0,78 & G. İçi & 23940,22 & 303 & 79,01 & & \\
\hline & & & & 5 Y1l ve Üzeri & 9 & 41,22 & 7,14 & 2,38 & Toplam & 24207,44 & 305 & & & \\
\hline & & & & Toplam & 306 & 37,11 & 8,91 & 0,51 & & & & & & \\
\hline \multirow{4}{*}{ 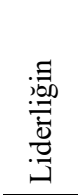 } & \multirow{4}{*}{\multicolumn{3}{|c|}{ 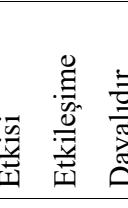 }} & 1-2 Y1l Aras1 & 147 & 37,05 & 7,35 & 0,61 & G. Aras1 & 516,95 & 2 & 258,47 & 4,00 & 0,02 \\
\hline & & & & 3-4 Y11 Aras1 & 150 & 35,57 & 8,81 & 0,72 & G. İçi & 19587,50 & 303 & 64,65 & & \\
\hline & & & & 5 Y1l ve Üzeri & 9 & 42,67 & 4,06 & 1,35 & Toplam & 20104,45 & 305 & & & \\
\hline & & & & Toplam & 306 & 36,49 & 8,12 & 0,46 & & & & & & \\
\hline
\end{tabular}

Tablo 5'de görülebileceği gibi, okul yöneticilerinin kuantum liderlik davranışları ölçeğinin alt boyutları puanlarının öğretmenlerin mevcut müdürler ile çalışma süresi değişkenine göre yapılan tek yönlü varyans analizi sonucunda "liderlik, lider-izleyenler ikileminde bir etkileşim alanıdır" alt boyutunda $\left(\mathrm{F}_{(2-303)}=2.07 ; \mathrm{p}>0.05\right)$, "liderlik olgusunun kesikliliği alt boyutunda" $\left(\mathrm{F}_{(2-303)}=1.69\right.$; $\mathrm{p}>0.05)$ aritmetik ortalamaları arasında anlamlı bir farklılık bulunamamış olmasına karşın, "liderlik yapılandırılamaz ve kestirilemez" $\left(\mathrm{F}_{(2-303)}=3.00 ; \mathrm{p}<0.05\right)$ ve "liderliğin etkisi etkileşime dayalıdır" alt boyutunda aritmetik ortalamalarının mevcut müdürle çalışma süresi değişkenine göre istatistiksel olarak anlamlı bir farklılık bulunmuştur $\left(\mathrm{F}_{(2-303)}=4.00 ; \mathrm{p}<0.05\right)$.
Tek yönlü varyans analizi sonrası hangi post-hoc çoklu karşılaştırma tekniğinin kullanılacağına ilişkin karar vermek amaciyla varyans analizinin ön koşulu olan Levene's testi ile grup dağılımlarının varyanslarının homojen olup olmadığ hipotezi denenmiş ve Liderliğin Etkisi Etkileşime Dayalıdır alt boyutunda $\left(\mathrm{L}_{\mathrm{v}(2-303)}=5.32, \mathrm{p}<\right.$ 0.05) dağılım normal olmadığı, buna karşın Liderlik Yapılandırılamaz ve Kestirilemez alt boyutunda dağılım normal dağılıma uyduğundan $\left(\mathrm{L}_{\mathrm{v}(2-303)}=1.64, \mathrm{p}>0.05\right)$ posthoc analizi yapılmıştır. Yapılan post-hoc LSD testi sonucunda, alt boyutta Levene İstatistiğine göre dağılım normal olmasına karşın, gruplar arasında anlamlı bir farklılığın olmadığı görülmektedir. 
Tablo 6.Öğretmenlerin inisiyatif alma davranışını mevcut müdür ile çalışma süresi değişkenine göre farklılaşma düzeyi

\begin{tabular}{|c|c|c|c|c|c|c|c|c|c|c|c|}
\hline \multirow{2}{*}{ Puan } & \multirow{2}{*}{$\begin{array}{l}\text { Mevcut Müdürle } \\
\text { Çalışma Süresi }\end{array}$} & \multicolumn{5}{|c|}{$f \overline{\mathrm{x}}_{\text {ve }} S S$ Děgerleri } & \multicolumn{4}{|c|}{ ANOVA Sonuçları } & \multirow[b]{2}{*}{$P$} \\
\hline & & $\mathrm{N}$ & $\overline{\mathrm{X}}$ & Ss & $\mathrm{Sh}_{\bar{x}}$ & Var. K. & $K T$ & $S d$ & $K O$ & $F$ & \\
\hline \multirow{4}{*}{ 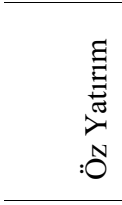 } & \multirow{4}{*}{$\begin{array}{l}\text { 1-2 Y1l Aras1 } \\
\text { 3-4 Y1l Aras1 } \\
5 \text { Y1l ve Üzeri } \\
\text { Toplam }\end{array}$} & \multirow{2}{*}{$\begin{array}{l}147 \\
150\end{array}$} & 30,95 & 4,47 & 0,37 & G. Aras1 & 44,61 & \multirow{2}{*}{2} & \multirow{3}{*}{$\begin{array}{l}22,31 \\
22,01\end{array}$} & \multirow[t]{2}{*}{1,01} & \multirow[t]{2}{*}{0,36} \\
\hline & & & 30,33 & 4,96 & 0,40 & G. İçi & 6668,00 & & & & \\
\hline & & & 32,00 & 3,32 & 1,11 & Toplam & 6712,61 & 305 & & & \\
\hline & & 306 & 30,68 & 4,69 & 0,27 & & & & & & \\
\hline \multirow{4}{*}{ 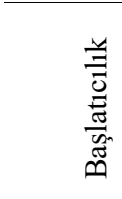 } & \multirow{4}{*}{$\begin{array}{l}\text { 1-2 Y1l Aras1 } \\
\text { 3-4 Y1l Aras1 } \\
5 \text { Y1l ve Üzeri } \\
\text { Toplam }\end{array}$} & \multirow{2}{*}{$\begin{array}{l}147 \\
150\end{array}$} & 25,94 & 3,12 & 0,26 & G. Aras1 & 48,70 & \multirow{2}{*}{2} & 24,35 & \multirow[t]{2}{*}{2,18} & \multirow[t]{2}{*}{0,12} \\
\hline & & & 26,05 & 3,57 & 0,29 & G. İçi & 3387,12 & & 11,18 & & \\
\hline & & 150 & 28,33 & 2,92 & 0,97 & Toplam & 3435,82 & & & & \\
\hline & & $\begin{array}{l}9 \\
306\end{array}$ & 26,06 & 3,36 & 0,19 & & & & & & \\
\hline \multirow{4}{*}{ 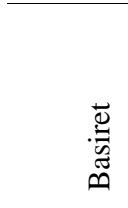 } & \multirow{4}{*}{$\begin{array}{l}\text { 1-2 Y1l Arası } \\
\text { 3-4 Y1l Arası } \\
5 \text { Y1l ve Üzeri } \\
\text { Toplam }\end{array}$} & \multirow{4}{*}{$\begin{array}{l}147 \\
150 \\
9 \\
306\end{array}$} & 36,71 & 4,81 & 0,40 & G. Aras1 & 88,28 & \multirow{4}{*}{$\begin{array}{c}2 \\
303 \\
305\end{array}$} & 44,14 & \multirow[t]{4}{*}{1,73} & \multirow[t]{4}{*}{0,18} \\
\hline & & & 36,13 & 5,29 & 0,43 & G. İçi & 7728,22 & & 25,51 & & \\
\hline & & & 39,11 & 4,70 & 1,57 & Toplam & 7816,50 & & & & \\
\hline & & & 36,50 & 5,06 & 0,29 & & & & & & \\
\hline \multirow{4}{*}{ 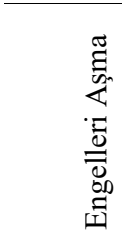 } & \multirow{4}{*}{$\begin{array}{l}\text { 1-2 Y1l Arası } \\
\text { 3-4 Y1l Arası } \\
5 \text { Y1l ve Üzeri }\end{array}$} & \multirow{2}{*}{$\begin{array}{l}147 \\
150\end{array}$} & 42,31 & 5,37 & 0,44 & G. Aras1 & 91,71 & 2 & 45,85 & \multirow[t]{4}{*}{1,45} & \multirow[t]{4}{*}{0,24} \\
\hline & & & 41,53 & 5,89 & 0,48 & G. İçi & 9612,17 & \multirow{3}{*}{$\begin{array}{l}303 \\
305\end{array}$} & \multirow[t]{3}{*}{31,72} & & \\
\hline & & 9 & 44,22 & 5,33 & 1,78 & Toplam & 9703,88 & & & & \\
\hline & & 306 & 41,98 & 5,64 & 0,32 & & & & & & \\
\hline
\end{tabular}

Tablo 6'da Eğitim Örgütlerinde İnisiyatif Alma Ölçeğinin alt boyutlarının öğretmenlerin mevcut müdürle çalışma süresi değişkenine göre farklılaşıp farklılaşmadığını belirlemek üzere yapılan tek yönlü varyans analizi sonuçları görülmektedir. İnisiyatif alma ölçeğinin "öz-yatırım" $\left(\mathrm{F}_{(2-}\right.$ $\left.{ }_{303)}=1.01 ; \mathrm{p}>0.05\right)$, başlatıcılı $\left(\mathrm{F}_{(2-303)}=2.18 ; \mathrm{p}>0.05\right)$, basiret $\left(\mathrm{F}_{(2-303)}=1.73 ; \mathrm{p}>0.05\right)$ ve engelleri aşma $\left(\mathrm{F}_{(2-303)}=\right.$ 1.45 ; $>>0.05$ )alt boyutlarında aritmetik ortalamalarının mevcut müdürle çalışma süresi değişkenine göre yapılan tek yönlü varyans analizi (ANOVA) sonucunda istatistiksel olarak anlamlı bir farklılık bulunmamaktadır. Bu bulgu nedeniyle varyansların homojenliği testi ve post-hoc analizi yapılmamıştır. Öğretmenlerin görüşlerine göre okul yöneticilerinin kuantum liderlik davranışlarını gösterme düzeyi ile öğretmenlerin inisiyatif alma davranışını gösterme düzeyi arasında ilişkiyi incelenmiştir. Söz konusu değişkenler arasındaki ilişki Pearson Çarpım Moment Korelâsyon ile test edilmiştir. Elde edilen bulgular Tablo 7'de gösterilmektedir. 
Tablo 7. Okul yöneticilerinin kuantum liderlik davranışlarını gösterme düzeyi ile öğretmenlerin inisiyatif alma davranışını gösterme düzeyi arasında ilişki

\begin{tabular}{|c|c|c|c|c|c|c|c|c|c|c|c|}
\hline ALT ÖLÇEKLER & & TKL1 & TKL2 & TKL3 & TKL4 & KL- & INS1 & INS2 & INS3 & INS4 & INS- \\
\hline \multirow{3}{*}{$\begin{array}{l}\text { KL1-Liderlik, Lider-İzleyenler } \\
\text { İkileminde Bir Etkileşim Alanıdır }\end{array}$} & $\mathbf{R}$ & 1 & $.86^{* *}$ & $.85^{* *}$ & $.82^{* *}$ & $.93^{* *}$ & .06 & $.17^{* *}$ & $.25^{* *}$ & $.11^{*}$ & .18 ** \\
\hline & $\mathbf{P}$ & &, 00 &, 00 &, 00 &, 00 &, 27 &, 01 &, 000 &, 05 & 001 \\
\hline & $\mathbf{N}$ & 306 & 306 & 306 & 306 & 306 & 306 & 306 & 306 & 306 & 306 \\
\hline \multirow{3}{*}{$\begin{array}{l}\text { KL2-Liderlik Yapılandırılamaz ve } \\
\text { Kestirilemez }\end{array}$} & $\mathbf{R}$ & $.86^{* *}$ & 1 & $.89^{* * *}$ & $.85^{* *}$ & $.95^{* *}$ & .04 & $.20^{* *}$ & $.31^{* *}$ & $.14^{*}$ & $.21^{* *}$ \\
\hline & $\mathbf{P}$ &, 00 & & .00 & .00 & .00 & .51 & .00 & .000 & .05 & .00 \\
\hline & $\mathbf{N}$ & 306 & 306 & 306 & 306 & 306 & 306 & 306 & 306 & 306 & 306 \\
\hline \multirow{3}{*}{ KL3-Liderlik Olgusunun Kesikliliği } & $\mathbf{R}$ & $.85^{* *}$ & $.89^{* *}$ & 1 & $.87^{* *}$ & $.96^{* *}$ & .05 & $.15^{*}$ & $.27^{* *}$ & .11 & $.18^{* * *}$ \\
\hline & $\mathbf{P}$ & .00 & .00 & & .00 & .00 & .44 & .01 & .000 & .05 & .05 \\
\hline & $\mathbf{N}$ & 306 & 306 & 306 & 306 & 306 & 306 & 306 & 306 & 306 & 306 \\
\hline \multirow{3}{*}{$\begin{array}{l}\text { KL4-Liderliğin Etkisi Etkileşime } \\
\text { Dayalıdır }\end{array}$} & $\mathbf{R}$ & $.82^{* *}$ & $.84^{* * *}$ & $.87^{* *}$ & 1 & $.94^{* *}$ & .05 & $.13^{*}$ & $.30^{* *}$ & $.12^{*}$ & $.16^{* *}$ \\
\hline & $\mathbf{P}$ &, 00 & .000 &, 00 & & .00 & .40 & .03 & .000 & .03 & .05 \\
\hline & $\mathbf{N}$ & 306 & 306 & 306 & 306 & 306 & 306 & 306 & 306 & 306 & 306 \\
\hline \multirow{3}{*}{$\begin{array}{l}\text { KUANTUM LİDERLİK } \\
\text { DAVRANIŞLARI } \\
\text { (Toplam Puan) }\end{array}$} & $\mathbf{R}$ & $.93^{* *}$ & $.952^{* *}$ & $.96^{* *}$ & $.94^{* *}$ & 1 & .05 & $.17^{* *}$ & $.28^{* *}$ & $.13^{*}$ & $.19^{* * *}$ \\
\hline & $\mathbf{P}$ &, 00 &, 000 &, 00 & .00 & & .37 &, 01 &, 00 & .03 & .01 \\
\hline & $\mathbf{N}$ & 306 & 306 & 306 & 306 & 306 & 306 & 306 & 306 & 306 & 306 \\
\hline \multirow{3}{*}{ Öz Yatırım } & $\mathbf{R}$ & .06 & .04 & .05 & .05 & .051 & 1 & $.36^{* *}$ & $.423^{* *}$ & $.36^{* *}$ & $.66^{* *}$ \\
\hline & $\mathbf{P}$ & .27 & .52 & .44 & .398 & .37 & & .00 & .000 & .00 & .00 \\
\hline & $\mathbf{N}$ & 306 & 306 & 306 & 306 & 306 & 306 & 306 & 306 & 306 & 306 \\
\hline \multirow{3}{*}{ INS 1-Başlatıcılık } & $\mathbf{R}$ & $.17^{* *}$ & $.20^{* * *}$ & $.15^{*}$ & $.13^{*}$ & $.17^{* * *}$ & $.36^{* *}$ & 1 & $.651^{* *}$ & $.61^{* *}$ & $.78^{* *}$ \\
\hline & $\mathbf{P}$ &, 05 & .00 & .05 & .02 & .01 & .00 & & .000 & .00 & .000 \\
\hline & $\mathbf{N}$ & 306 & 306 & 306 & 306 & 306 & 306 & 306 & 306 & 306 & 306 \\
\hline \multirow{3}{*}{ INS 1-Basiret } & $\mathbf{R}$ & $.25^{* *}$ & $.31^{* *}$ & $.27^{* *}$ & $.23^{* *}$ & $.28^{* *}$ & .4182 & $.65^{* *}$ & 1 & $.75^{* *}$ & $.89^{* *}$ \\
\hline & $\mathbf{P}$ & .00 & .00 & .00 & .00 & .00 &, 00 & .00 & &, 00 & .00 \\
\hline & $\mathbf{N}$ & 306 & 306 & 306 & 306 & 306 & 306 & 306 & 306 & 306 & 306 \\
\hline \multirow{3}{*}{ INS 3-Engelleri Aşma } & $\mathbf{R}$ & $.12^{*}$ & $.14^{*}$ & .11 & $.12^{*}$ & $.13^{*}$ & $.36^{* *}$ & $.61^{* *}$ & $.749^{* *}$ & 1 & $.87^{* *}$ \\
\hline & $\mathbf{P}$ & .04 &, 05 & .05 & .03 &, 03 &, 00 &, 00 & .000 & & .00 \\
\hline & $\mathbf{N}$ & 306 & 306 & 306 & 306 & 306 & 306 & 306 & 306 & 306 & 306 \\
\hline \multirow{3}{*}{ İNİSIYATİF ALMA(Toplam) } & $\mathbf{R}$ & $.18^{* *}$ & $.21^{* *}$ & $.17^{* *}$ & $.16^{* * *}$ & $.19^{* *}$ & $.66^{* *}$ & $.78^{* *}$ & $.889^{* *}$ & $.87^{* * *}$ & 1 \\
\hline & $\mathbf{P}$ &, 01 & .00 & .05 & .01 & .01 & .00 & .00 & .000 & .00 & \\
\hline & $\mathbf{N}$ & 306 & 306 & 306 & 306 & 306 & 306 & 306 & 306 & 306 & 306 \\
\hline
\end{tabular}

Tablo 7'ye göre kuantum liderlik ölçeğinin alt boyutları ile inisiyatif alma ölçeğinin alt boyutları ve/veya toplam puanları arasındaki korelasyonun değerlerinin $\mathrm{r}=0.00$ ile $\mathrm{r}=0.30$ arasında olması iki değişken arasındaki ilişkinin genel olarak “düşük” olduğunu görülmektedir. Buna karşın inisiyatif alma ölçeğinin "basiret" alt boyutu ile "Liderlik Yapılandirılamaz ve Kestirilemez" alt boyutu arasinda $\mathrm{r}=0.31$ olması iki boyut arasındaki ilişkinin "orta" düzeyde olduğu söylenebilir. Her iki ölçeğin toplam puanları arasındaki $\mathrm{r}=0.19$ olması iki değişken arasındaki ilişkinin pozitif yönlü istatistiksel olarak anlamlı ve "düşük" düzeyde olduğunu göstermektedir.

\section{Sonuç, Tartıșma ve Öneriler}

\subsection{Sonuç ve Tartışma}

Öğretmen görüşlerine göre okul yöneticilerinin kuantum liderlik davranışlarına ilişkin gerçekleştirilen betimsel analizler sonucunda okul yöneticilerinin; "Liderlik, Liderİzleyenler İkileminde Bir Etkileşim Alanıdır","Liderlik Yapılandirılamaz ve Kestirilemez", "Liderlik Olgusunun Kesikliliği Liderliğin Etkisi Etkileşime Dayalıdır" alt boyutlarında "çoğu zaman" kuantum liderlik davranışlarını gösterdikleri sonucuna varılmıştır. Benzer şekilde Turan (2017) ve Erçetin ve diğerleri de (2018) öğretmen görüşlerine göre okul yöneticilerinin kuantum liderlik davranış düzeylerinin çoğu zaman gösterdikleri sonucuna ulaşmışlardır. Kayman-Ertürk (2008) ise Türkiye'deki Mesleki Eğitim ve Öğretimin Güçlendirilmesi Projesi kapsamında yapılan çalışmada, okul müdürlerinin görüşlerine göre okul müdürlerinin kuantum liderlik davranış gösterme düzeyinin yüksek olduğu sonucuna ulaşarak bu durumu desteklemektedir. $\mathrm{Bu}$ noktadan hareketle okul müdürlerinin yönetimde her zaman olmasa da çoğu zaman; iş birliğine ve etkileşimin gücüne inandıkları, öğretmenlere yeri geldiğinde okul yönetiminin faydasını gözeterek lider olma firsatı verdikleri, 
belirsizlikleri en verimli șekilde yöneterek risk alabildikleri, elde edilen başarıları paylaşabildikleri, okul içinde informal iletişime önem veren esnek bir yönetim anlayışına sahip oldukları söylenebilir. Weick (1976) eğitim örgütlerindeki bürokratik anlayışın birçok noktada yetersiz kalacağını ifade etmiştir. $\mathrm{O}$ zamandan yaklaşık 50 yıl sonra gerek dünyada meydana gelen değişim ve dönüşüm hızının artması gerekse yaşanan paradigmik dönüşüm ile bu gerçeğin daha da derinleştiği söylenebilir. Diğer yandan Wheatley (2006) ise kuantum liderliği benimseyen okul yöneticilerinin enerji akışına odaklanarak, enerjinin doğru ve faydalı şekilde kullanılmasını sağladıklarını ve örgütün amaçlarına ulaşmasını kolaylaştırdıklarını ifade etmektedir. Araştırmanın sonucuna dayanarak okul yöneticilerinin her zaman olmasa da çoğu zaman okullarda enerji akışını yöneterek, olasılıkları algılayan, lider ve izleyenleri bir bütün olarak düşünen ve liderliğin kesikli bir olgu olduğunun farkında oldukları söylenebilir. Wheatley (2006) ve Weick (1976)'in ifadelerine göre bu durumun olumlu bir sonuç olduğu söylenilebilir.

Öğretmenlerin inisiyatif alma davranış düzeyine ilişkin gerçekleştirilen betimsel analiz sonucunda genel olarak öğretmenlerin inisiyatif alma davranışlarının çoğu zaman gösterdikleri söylenebilir. Davranış alt boyutları bağlamında incelendiğinde; öğretmenlerin "engelleri aşma" davranışını her zaman, "öz-yatırım" ve "basiret gösterme" davranışlarını çoğu zaman, "başlatıcılık" davranışını ise ara sıra sergiledikleri ifade edilebilir. Aritmetik ortalamalara bakıldığında öğretmenlerin en çok engelleri aşma, en az ise başlatıcılık davranışlarını sergiledikleri görülmektedir. İlgili literatürde Nayır ve Taşkın (2017) öğretmenlerin inisiyatif alma davranışlarını tüm alt boyutlarda orta düzeyde sergilediklerini tespit etmiştir. Taşkın (2016) ise öğretmenlerin inisiyatif iklimini belirlemeye dönük çalışmasında "kararsızım" düzeyinde sonuca ulaşmıştır. Yurt dişındaki çalışmalar incelendiğinde ise Frese ve diğerleri (1997) ve Frese ve Fay (2001) çalışanların sorumluluk alma ve inisiyatif alma davranış düzeylerinin normal düzeyde olduğunu belirtmektedirler. Zimmerman'a (2006) göre öğretmenlerin değişime karşı dirençlerinin kırılmasının temel şartı, değişimin gerekliliğine ikna olmalarıdır. Aksi durumda var olan düzeni devam ettirmeye meyilli olmaktadırlar. Araştırmanın bu sonucundan hareket ile öğretmenlerin zorluklar karşısında inisiyatif alarak engelleri aşmaya dönük davranış düzeyleri en yüksek, inisiyatif alarak bir işi kendiliğinden başlatmaya ilişkin davranış düzeyleri ise en düşük düzeydedir. Buna göre öğretmenler karşılarına sadece engeller çıktığında inisiyatif almanın gerekliliğinin farkına vardıklarından "engelleri aşma" boyutunda inisiyatif alabilme düzeylerinin yüksek, ancak var olan düzeni devam ettirmeye ya da değişime olan dirençten ötürü "bir işi kendiliğinden başlatmaya" ilişkin inisiyatif davranışlarının diğer boyutlardan daha düşük seviyede olduğu söylenebilir.

Öğretmen görüşlerine göre okul yöneticilerinin kuantum liderlik davranış düzeyleri öğretmenlerin kariyer evrelerine göre "Liderlik, Lider-İzleyenler İkileminde Bir Etkileşim Alanıdır","Liderlik Yapılandırılamaz ve Kestirilemez", "Liderlik Olgusunun Kesikliliği" alt boyutlarında istatiksel olarak anlamlı bir farklılık göstermezken, "Liderliğin Etkisi Etkileşime Dayalıdır" alt boyutlarında istatiksel olarak anlamlı bir fark göstermektedir. Bu farklılığa göre kariyere giriş evresi ve durulma evresinde bulunan öğretmenler deneycilik ve uzmanlık evresindeki öğretmenlere göre liderliğin etkileşime dayalı olduğu görüşüne daha fazla katıldığı söylenilebilir. Erçetin, Çevik ve Çelik (2018) öğretmenlerin mesleki kıdemlerinin okul yöneticilerinin kuantum liderlik davranış düzeylerine ilişkin görüşlerini etkilemediği sonucuna ulaşmışlardır. Turan (2017) benzer şekilde öğretmenlerin mesleki kıdemlerine göre okul yöneticilerinin kuantum liderlik davranışlarına ilişkin görüşlerin değişmediğini; ancak 30 yıl ve üzeri görev yapan öğretmenler, okul yöneticilerinin kuantum liderlik davranışlarına ilişkin daha olumlu bir görüşe sahip olduklarını ifade etmektedir. Diğer bir ifade ile okul müdürlerinin, 30 yıl ve üzeri mesleki kıdemi bulunan öğretmenlere karşı daha fazla kuantum liderlik davranışları sergiledikleri söylenebilir. Kayman-Ertürk (2008) ise okul yöneticilerinin mesleki kıdemlerine göre kuantum liderlik davranışlarını belirlemeye yönelik çalışmasında, okul müdürlerinin mesleki kidemlerinin kuantum liderlik davranışlarında belirleyici bir değişken olmadığı sonucuna ulaşmıştır. Yine okul yöneticilerinin görüşlerine göre yeni bilim liderlik davranışlarını inceleyen Akpil (2016) okul müdürlerinin mesleki kıdemleri ne olursa olsun yeni bilim liderliğe karşı olumlu görüş sunduklarını tespit ederek araştırmanın bu sonucunu desteklemektedir. Özet ile Kayman-Ertürk (2008) ve Akpil (2016) birbirini destekledikleri söylenebilir. Alanyazındaki ilgili çalışmalara bakıldığında öğretmenlerin kariyer evrelerine göre okul yöneticilerinin kuantum liderlik davranışına ilişkin görüşleri büyük ölçüde birbirlerini destekledikleri söylenebilir. Bu çalışmada ise kuantum liderlik davranışının üç boyutu öğretmenlerin kariyer evrelerine göre fark oluşturmazken; sadece "kuantum liderliğin etkisi etkileşime dayalıdır" boyutuna ilişkin kuantum liderlik davranışları, kariyere giriş ve durulma evrelerindeki öğretmenler tarafından daha fazla algılandığı söylenilebilir. Bir başka ifade ile okul yöneticilerinin, kariyere giriş ve durulma evrelerindeki öğretmenler ile diğer kariyer evrelerindeki öğretmenlere göre daha fazla informal ilişkiler kurarak, onları bürokrasinin gerekliliklerine daha az maruz bırakarak etkileşimi arttırdığını, bu etkileşim sayesinde güç elde ettikleri söylenebilir. Diğer yandan kariyere giriş ve durulma evrelerindeki öğretmenlerin okul müdürü ile daha fazla etkileşime girebilmeleri diğer evrelerdeki öğretmenler ile aralarındaki kuşak farklılığından da oluşabileceği düşünülebilir. Adıgüzel, Batur ve Ekşili' ye göre (2014) 1980- 1996 yılları arası doğan Y kuşağı ile beraber ortaya çıkan mobil yakalı çalışanlar; e-devlet, e- medya, e-okul, vb. teknolojik gelişimleri daha yakından takip etmekte olup etkileşim düzeyini arttırmaktadırlar. Buna ilaveten Y kuşağı hiyerarşinin gerekliliğini kabullenmezlerken, 1965 ile 1979 yılları arası doğan X kuşağı ise hiyerarşi ve bürokrasinin gerektirdiği formal iletişimin dişına çıkmakta zorlanmaktadırlar (Seymen, 2017). Bu noktadan hareketle kariyere giriş ve durulma evrelerindeki öğretmenlerin okul müdürlerinin etkileşime yönelik davranışlarını diğerlerine göre daha yüksek düzeyde algıladıkları düşünülebilir.

Öğretmenlerin inisiyatif alma davranış düzeyleri, kariyer evresi değişkenine göre başlatıcılık, basiret ve engelleri aşma alt boyutlarında istatistiksel olarak anlamlı bir fark göstermezken, öz yatırım boyutunda kariyer evresi değişkenine göre istatistiksel olarak anlamlı bir fark görülmektedir. Farklılığın kaynağı istatistiksel olarak bulunamasa da aritmetik ortalamalara bakıldığında kariyer 
evrelerinde ilerledikçe öğretmenlerin öz-yatırımsal davranışlara ilişkin olumlu görüşleri azaldığ görülmektedir. Taşkın (2016) ise öğretmenlerin mesleki kıdem değişkeninin inisiyatif alma davranışının düzeyini hiçbir alt boyutta etkilemediği bulgusuyla bu sonucu yüksek düzeyde desteklerken, Nayır ve Taşkın (2017) ise öğretmenlerin mesleki kıdemlerinin öz-yatırım, basiret ve engelleri aşma boyutlarında anlamlı bir fark göstermediğini; ancak kıdemi 21 yıl ve üzeri (sakinlik evresi) olanların, 1120 yıl (deneycilik evresi) olanlara göre başlatıcılık boyutuna ilişkin görüşlere daha çok katıldıklarını belirtmektedirler. Alanyazında öğretmenlerin kariyer evreleri/ kıdem değișkenlerine göre inisiyatif alma davranıș düzeylerini belirleyen söz konusu iki çalışma, araştırmanın bu sonucunu büyük ölçüde desteklediği görülmektedir. Bu noktadan hareketle öz-yatırım boyutunun ağırlıklı ortalamalarına bakıldığında kariyere giriş evresinde bulunan öğretmenler, diğer evrelerde bulunan öğretmenlere göre daha yüksek düzeyde öz yatırımsal davranışlar sergilediği söylenebilir. Araştırmanın bu bulgusu Bakioğlu'nun (1996) çalışmasında kariyere giriş evresindeki öğretmen nitelikleri ile uyum sağlamaktadır. Bakioğlu'na (1996) göre kariyere giriş evresindeki öğretmenler zamanlarını sınıf ortamını ve günlük öğretim durumlarını kavramak için kendilerini geliştirmeye harcamaktadırlar. Öğretmenlerin kariyer evrelerinde ilerledikçe mesleklerine ilişkin öz- yatırımsal davranışlarının azalmasının nedenleri ilgi çekicidir. Tüm bunlara ek olarak inisiyatif alma davranıșının diğer boyutlarında öğretmenler kariyer evrelerinden bağımsız şekilde benzer davranış gösterdiği söylenebilir.

Öğretmen görüşlerine göre okul yöneticilerinin "Liderlik, Lider-İzleyenler İkileminde Bir Etkileşim Alanıdır" ve "Liderlik Olgusunun Kesikliliği" alt boyutlarında kuantum liderlik davranış düzeyleri, öğretmenlerin mevcut müdür ile çalışma süresi değişkenine göre istatistiksel olarak anlamlı bir farklılık göstermezken, "Liderliğin Etkisi Etkileşime Dayalıdır" ve "Liderlik Yapılandırılamaz ve Kestirilemez" alt boyutlarında istatiksel olarak anlamlı bir fark göstermektedir. Turan (2017) ise sadece "Liderlik, Liderİzleyenler İkileminde Bir Etkileşim Alanıdır" alt boyutunda mevcut müdür ile çalışma süresine göre anlamlı bir fark tespit ederek farklı bir sonuca ulaşmıştır. Turan' in (2017) çalışmasının sonuçlarına göre, okul müdürleri ile birlikte 12 y1l çalışan öğretmenler, okul müdürlerinden kendilerini ayrı olarak görmez ve aralarında bir etkileşim olduklarını düşünürler. Diğer bir ifade ile okul müdürleri çalışmaya yeni başlayan öğretmenler ile daha fazla etkileşim alanı oluşturdukları söylenilebilir. Erçetin ve diğerleri (2018) ise mevcut müdür ile çalışma süresi, kuantum liderlik davranış düzeyine ilişkin görüşlerde anlamlı bir fark oluşturmadığı sonucuna ulaşmıştır. $\mathrm{Bu}$ araştırmada ise mevcut okul müdürü ile çalışma süresine göre "Liderliğin Etkisi Etkileşime Dayalıdır" ve "Liderlik Yapılandırılamaz ve Kestirilemez" boyutlarında anlamlı bir farklılık oluşmasına rağmen, bu farkın kaynağı istatistiksel olarak saptanamamıştır. Ancak aritmetik ortalamalara bakıldığında, okul müdürleri ile beş yıldan fazla görev yapan öğretmenler liderliği; etkileşime dayalı, yapılandırılamayan ve kestirilemeyen bir süreç olarak değerlendirdikleri söylenebilir. Bunun yanında okul müdürleri daha fazla süre beraber çalıştıkları öğretmenler üzerinde daha fazla etkiye ya da güce sahip oldukları şeklinde yorumlanabilir.
Öğretmenlerin okulda çalışma süresi ve mevcut müdür ile çalışma süresi değişkenlerine göre öz yatırım, başlatıcılık, basiret ve engelleri aşma alt boyutlarında inisiyatif alma davranış düzeyleri istatistiksel olarak anlamlı bir fark oluşturmamaktadır. İlgili alan yazında eğitim örgütlerinde inisiyatif alma davranışı, öğretmenin okulda ve mevcut müdür ile çalışma süreleri değişkenleri bağlamında incelenmediği görülmektedir. Elde edilen bulgulardan hareketle öğretmenlerin okulda çalışma süreleri ve mevcut müdür ile çalışma sürelerinden bağımsız olarak inisiyatif alma davranışlarına ilişkin görüşleri benzerlik gösterdiği söylenebilir. Bursalığlu'na göre (2002) okul yönetimlerindeki bürokratik anlayış beraberinde bazı kısitlamalar da meydana getirebilmektedir. Bu noktadan hareketle normalde inisiyatif alma davranışının, okulda çalışma süresi ve mevcut müdür ile çalışma süresine göre anlamlı bir fark oluşturması beklenirken, elde edilen sonucun sebebi; okulların bürokrasiye dayalı olarak yönetilmesi ve bürokrasinin getirdiği keskin yaptırımlar olarak yorumlanabilir.

Araştırmanın bir diğer sonucuna göre, okul yöneticilerinin kuantum liderlik davranış düzeyi ile öğretmenlerin inisiyatif alma davranışını gösterme düzeyi arasında anlamlı bir ilişki olduğu görülmektedir. İnisiyatif alma davranışının basiret alt boyutu ile kuantum liderlik davranışının "liderlik yapılandırılamaz ve kestirilemez" alt boyutları arasındaki ilişki düzeyinin diğer alt boyutlar arasındaki ilişki düzeyinden fazla çıkması ilgi çekicidir. $\mathrm{Bu}$ noktadan hareket ile liderliğin yapılandırılamaz ve kestirilemez olduğu okullarda belirsizliklere karşı yöneticilerin olası durumları belirleyerek en sağlıklı kararı vermesi, öğretmenleri basiretli olmaları noktasında cesaretlendikleri söylenilebilir. Diğer bir deyişle belirsizlikler karşısında risk alabilen, kaos ortamlarını başarılı bir şekilde idare edebilen okul yöneticileri ile çalışan öğretmenler, çıkması muhtemel problemlere karşı proaktif (basiret) yani problem oluşmadan engelleyen bir tutum sergilemekte oldukları yönünde yorumlanabilir. $\mathrm{Bu}$ sayede okullarda olası belirsizlikler en verimli şekilde yönetilmiş olur.

Gerek yurtdışı gerekse yurt içi ilgili alanyazında kuantum liderlik davranışı ile inisiyatif alma davranışını bir arada çalışan bir araştırmaya rastlanamamıştır; ancak inisiyatif alabilme ve inisiyatif aldırmaya teşvik etme, liderlik tarihinin en başından bu yana liderlere atfedilen bir özellik olmuştur (Stodgill, 1948; Stodgill, 1974). Bunun yanında Bass (1990), modern liderlik kuramlarından olan karizmatik liderliğin etkisinin inisiyatif alma davranışı ile artacağını belirterek, liderlik ile inisiyatif alma davranışını bağdaştırmaktadır (Frese \& Fay, 2002). Benzer şekilde dönüşümcü liderlik davranışları da inisiyatif alma davranışını gerektirdiği varsayılmaktadır (Bass \& Avilio, 1990). Bu çalışmanın konusu olan kuantum liderlik paradigması ise diğer liderlik kuramlarından farklı olarak, sadece liderin inisiyatif alma davranışı göstermesinin yanı sıra izleyenleri de inisiyatif almaları noktasında cesaretlendirilebileceğini varsaymaktadır. Bu bağlamda araştırmada kullanılan, okul yöneticilerinin kuantum liderlik davranış düzeylerini belirleyen ölçeğin bazı maddeleri okul müdürlerinin birlikte çalıştığ öğretmenlere inisiyatif alma davranışını sergilemeleri yönünde firsat verip vermediğini sorgulama yönündedir. 
Elde edilen sonuçlardan yola çıkarak çalışmanın problem durumu olarak tanımlanan, ögrretmen görüşlerine göre okul yöneticilerinin kuantum liderlik davranışları ile öğretmenlerin inisiyatif alma davranışı arasındaki ilişki durumunun anlamlı olduğu görülmektedir. Bu ilişkinin düzeyi düşük çıkmasının sebebi araştırmanın örneklemine bağlanılabileceği gibi inisiyatif alma davranışını etkileyebilecek başka değişkenlerin var olabileceği de dikkate alınmalıdır. Bu değişkenlerden biri Hofstede' ye (2001) göre kültürün çalışma yaşamına etkisi olduğu düşünülebilir. Hofstede'ye (2001) göre kültür boyutlarından sayılan "güç mesafesi" arttıkça çalışanların inisiyatif alma davranışı azaldığı görülmektedir. Güç mesafesi, üstlerle astlar arasındaki mesafe durumu olarak tanımlanmakta olup çalışanların ve yöneticilerin karar alma biçimlerini etkilemektedir. Hofstede'nin (2001) çalışmasına göre Türkiye bu anlamda ortalama değerin üstünde yer almaktadır. Yani Türkiye'de örgüt yönetiminde ast ve üst arasındaki hiyerarşik yapının uzun olduğu şeklinde yorumlanabilir. $\mathrm{Bu}$ duruma paralel olarak Türkiye'deki eğitim örgütleri merkeziyetçi, bürokratik bir yapıya sahiptirler (Bursalığlu, 2002). Akın 'a (2012) göre merkeziyetçi yapıya sahip eğitim örgütlerinde esnek olmayan üst yönetim, alt yönetimlere de esnek olma firsatı tanımamaktadırlar. Aydın (2000) eğitim örgütlerinde okul müdürlerine yetki ve inisiyatif tanınmadığını ifade etmektedir. Bu noktadan yola çıkarak üst yönetimlerce hareket alanları daraltılmış okul müdürleri, öğretmenlerin inisiyatif alma düzeyine katkılarının düşük olabileceği göz önünde bulundurulabilir.

\section{2. Öneriler}

$\mathrm{Bu}$ araştırmada, okul yöneticilerinin kuantum liderlik davranışlarının öğretmenlerin inisiyatif alma davranış düzeyleri arasında pozitif bir ilişki olduğu öğretmen görüşlerine dayalı olarak ortaya koyulmaktadır. $\mathrm{Bu}$ bağlamda öğretmenlerin daha fazla inisiyatif alabilmeleri için okul yöneticilerinin liderlik davranışlarından özelde kuantum liderlik davranışlarını sergilemesi önemli bir faktör olarak düşünülmektedir. Buna göre okul yöneticilerinin kuantum liderlik davranışını daha fazla göstermelerine uygun bir örgüt yapısı oluşturulması önerilebilir.

- Öğretmenler, okul yöneticilerinin kuantum liderlik davranışlarını her zaman olmasa da çoğu zaman sergilediklerini düşünmektedirler. $\mathrm{Bu}$ bağlamda politika yapıcı ve uygulayıcılara okul yöneticilerinin kuantum liderlik biçimini kavramalarını sağlamayı kapsayan çalışmalar yapmaları önerilmektedir. $\mathrm{Bu}$ sayede okul müdürlerinin söz konusu liderlik biçimini sergileme düzeyleri daha da artacağı varsayılmaktadır. Yine öğretmenlerin inisiyatif alma davranışını her zaman olmasa da çoğu zaman sergiledikleri sonucu elde edilmiştir. Ancak öğretmenler bir işi kendiliğinden başlatma davranışını diğer inisiyatif alma davranışlarından daha düşük düzeyde sergilemektedirler. $\mathrm{Bu}$ noktadan hareketle okul yöneticilerine öğretmenlerin inisiyatif alabilecekleri, özellikle bir işi kendiliğinden başlatabilmeleri noktasında cesaretlendirmeleri ve onlara firsat oluşturmaları önerilmektedir.

-Öğretmenlerin kariyer evrelerine göre okul yöneticilerinin etkileşime dayalı kuantum liderlik davranışlarına ilişkin görüşleri kariyere giriş ve durulma evrelerindeki öğretmenler tarafından daha çok algılanırken deneycilik ve uzmanlık evrelerindeki öğretmenler tarafından daha az algılanmaktadır. Bu sonuca ilişkin olarak okul müdürlerinin deneycilik ve uzmanlık evrelerindeki öğretmenler ile etkileşimi arttırmaya yönelik davranışlar sergilemeleri ya da bu evrelerindeki öğretmenlere etkileşim gösterebilecekleri firsatlar verilmesi önerilmektedir.

-Öğretmenlerin inisiyatif alma davranış düzeyleri özyatırım alt boyutunda kariyer evreleri değişkenlerine göre istatistiksel olarak farklılık göstermektedir. Öğretmenlerin kariyer evrelerine göre inisiyatif alma davranışına ilişkin görüşleri incelendiğinde kariyer evrelerinde ilerledikçe özyatırımsal davranış düzeyinin azaldığı görülmektedir. Öğretmenlerin kariyer evrelerinde ilerledikçe kendilerini geliştirmekten vazgeçmelerini önlemek ve öz-yatırımsal davranışlarını devam ettirmelerini sağlamak amacıyla politika yapıcı ve uygulayıcılara bu konuda hizmet içi eğitimlerinin ulaşılabilirliğinin artırılması, cazipleştirilmesi; dil tazminatının daha ulaşılabilir hale getirilmesi, yüksek lisans eğitimi ve doktora eğitiminin mesleki getirilerini arttırma vb. gibi teşvik edici çalışmalar yapmaları önerilebilir.

-Öğretmen görüşlerine göre okul yöneticilerinin kuantum liderlik davranıșları ile öğretmenlerin inisiyatif alma davranış düzeyleri arasında pozitif yönde anlamlı bir ilişki olduğu sonucuna ulaşılmıştır. Kuantum liderlik davranışlarının okul iklimine olumlu yönde katkıları ilgili kavramsal çerçevede yer almaktadır. Bunların yanında bu araştırma ile okul yönetiminde kuantum liderlik davranışlarının, öğretmenlerin inisiyatif almalarını olumlu etkilediği anlaşılmaktadır. İlgili alanyazında örgütlerde inisiyatif alma davranış düzeyi üst yönetimlerin bu duruma ne kadar firsat tanıdığı ile ilişkili olduğu ifade edilmektedir. Karmaşık ve kaotik yapılar olan okullarda üst yönetimler tarafindan okul müdürlerine okul yönetimi ya da öğretimin düzenlenmesi konusunda inisiyatif alabilecekleri yetkiler verilebilirse okul yöneticilerinin de aynı konularda öğretmenlere inisiyatif almaları için imkan sağlayabileceği düşünülmektedir. $\mathrm{Bu}$ bağlamda politika yapıcılar ve uygulayıcılar tarafindan öğretmenlerin inisiyatif düzeylerinin artması için okul müdürlerinin kuantum liderlik davranışlarını teşvik eden ve bu davranış düzeyini artıran çalışmalar yapılabilir.

- Araştırma ilkokul, lise gibi farklı eğitim kademelerinde yürütülebilir. Böylelikle farklı eğitim kademelerinde elde edilen sonuçları kıyaslayabilme firsatı elde edilmiş olur.

- Okul yöneticilerinin kuantum liderlik davranış düzeyleri devlet ve özel okullarda karşılaştırılmalı olarak incelenebilir.

- Okul yöneticilerinin kuantum liderlik davranış düzeyleri ile okul müdürlerinin inisiyatif alma davranışları arasındaki ilişki durumu araştırılabilir. Böylelikle eğitim örgütlerinde kuantum liderlerin inisiyatif alma davranışlarını ne düzeyde gösterebildikleri belirlenebilir.

-Araştırma farklı desenlerde çalışılabilir. Böylelikle ilişki durumunun varlığına yönelik bulguların yanında bu ilişki durumunun nedenlerine yönelik bulgular da elde edilebilir. Bu bağlamda okul müdürlerinin görüşlerine göre 
öğretmenlerin inisiyatif alma düzeyleri ve öğretmen görüşlerine göre okul müdürlerinin kuantum liderlik davranış düzeyleri nitel yöntemlerle sorgulanarak karma ya da nitel bir çalışma yapılabilir.

- Okul yöneticilerinin kuantum liderlik davranışları ile öğretmenlerin inisiyatif alma düzeyi arasındaki ilişki durumunun düşük çıkması, öğretmenlerin inisiyatif alma davranışlarını etkileyen başka değişkenlerin olabileceğini akla getirmektedir. Tartışma kısmında bu değişkenlerin neler olabileceğine ilişkin yorumlar yer almaktadır. Sonra ki araştırmacılar bu yorumları da göz önünde bulundurarak öğretmenlerin inisiyatif alma davranış düzeylerini etkileyebilecek değişkenleri sorgulayabilirler.

\section{Kaynakça}

Adıgüzel, O., Batur, H. Z. ve Ekşili, N. (2014). Kuşakların değişen yüzü ve y kuşağı ile ortaya çıkan yeni çalışma tarzı: Mobil yakalılar. Süleyman Demirel Üniversitesi Sosyal Bilimler Enstitüsü Dergisi, l(19), 165-182.

Akın, U. (2012). Örgüt ve yönetimde inisiyatif alma. Ankara: Pegem Akademi.

Akın, U. (2014). Okul müdürlerinin inisiyatif alma düzeyleri ile öz-yeterlikleri arasındaki ilişki. Kuram ve Uygulamada Ĕgitim Yönetimi Dergisi, 20(21), 25-149.

Akın, A. ve Anlı, G. (2011). Bireysel gelişim inisiyatifi ölçeğinin Türkçeye uyarlanmas1: Geçerlilik ve güvenirlilik çalışması. Mersin Üniversitesi Eğitim Fakültesi Dergisi, 7(1), 42-49.

Akpil, Ş. (2016). Yeni bilim ve liderlik. (Yayınlanmamış yüksek lisans tezi). Yıldız Teknik Üniversitesi, İstanbul.

Aydın, M. (2000). Eğitim yönetimi. Ankara: Hatipoğlu Yayınları.

Bakioğlu, A. (1996). Ö̆gretmenlerin kariyer evreleri: Türkiye'de resmi lise ögretmenleri üzerinde yapılan bir araştırma. 2. Ulusal Eğitim Sempozyumu Bildirileri. 18-20 Eylül. İstanbul.

Bass, B. M., \& Avolio, B. J. (1990). The implications of transactional and transformational leadership for individual, team, and organizational development. Research in Organizational Change and Development, 4 231-272.

Bass, B. M. (1990). Bass and Stogdill's handbook of leadership: A survey of theory and research. New York: Free Press.

Bursalığlu, Z. (2002). Okul yönetiminde yeni yapl ve davranışlar. Ankara: Pegem Akademi.

Bush, T. (2008). Leadership and management development in education. London: SAGE Publication.

Capra, F. (2012). Batı düşüncesinde dönüm noktası. Çev. M. Armağan. İstanbul: İnsan Yayınları.
Çakmak, E., Gündüz, H. B. ve Korumaz, M. (2015). Eğitim örgütlerinde inisiyatif alma: Bir ölçek geliştirme çalışması. International Journal of Human Sciences, 12(2), 327-342.

Erçetin, Ş. Ş. (2000). Lider sarmalında vizyon. Ankara: Nobel Yayın.

Erçetin, Ş. Ş. (2001). Yönetimde yeni yaklaşımlar. Ankara: Nobel Yayın Dağıtım.

Erçetin, Ş. Ş, Potas, N. Açıkalın, Ş. N.,Turan, S. ve Bisaso, S. M. (2016). A study for developing a viable quantum leadership scale. International Congress On Political, Economicand Social Studies Abstracts Book. Ankara-TURKEY (Baskıda)

Erçetin, Ş. Ş., Çelik, M. ve Çevik, M. S. (2018). Okul müdürlerinin kuantum liderlik davranışlarını gerçekleştirme düzeyleri. Uluslararası Liderlik Çalışmaları Dergisi: Kuram ve Uygulama, 1(2), 109-124.

Frese, M., Kring, W., Soose, A., \& Zempel, J. (1996). PI at work: Differences between East and West Germany. Academy of Management Journal, 39(1), 37-63.

Frese, M., Fay, D., Hilburger, T., Leng, K., \& Tag, A. (1997). The concept of personal initiative: Operationlization, reliability and validity in two German samples. Journal of Occupational and Organizational Psychology, 70(1) 139-161.

Frese, M., \& Fay, D.(2001). the concept of personal 1nitiative: Department of psychology University of Giessen. Human Performance, 14(1), 97-124.

Frese, M., \& Fay, D. (2002). Personal initiative: An active performance concept for work in the 21st century. Research in Organizational Behavior, 23(1), 133487.

Frese, M., Garst, H., \& Fay, D. (2007). Making things happen: Reciprocal relationships between work characteristics and personal nnitiative in a fourwave longitudinal structural equation Model. Journal of Applied Psychology, 92(4), 1084-1112.

Fris, J., \& Lazaridou, A. (2006). An additional way of thinking about organizational life and leadership: The quantum perspective. Canadian Journal of Educational Administration and Policy. 1(8), 1-29.

Garmston, R., \& Wellman, B. (1995). Adaptive school in a quantum universe-educational leadership. Self Renewing Schools, 52(1), 7-6.

Hofstede, G. (2001). Culture's consequences: Comparing values, behaviors, institutions, and organizations across nations. California: Sage Publications.

Karasar, N. (2013). Bilimsel araştırma yöntemi. Ankara: Nobel Yayınları.

Kayman-Ertürk, E. A. (2008). Türkiye'deki mesleki eğitim ve öğretimin güçlendirilmesi projesi (MEGEP) içindeki yaygınlaştırıcı okul yöneticilerinin kuantum liderlik davranışlarının gerçekleştirme 
düzeyleri. (Yayınlanmamıș yüksek lisans tezi). Hacettepe Üniversitesi, Ankara.

Konan, N. (2015). Eğitim yönetiminde yeni liderlik yaklaşımları. Ankara: Pegem Akademi.

Kuhn, T. (2018). Bilimsel devrimlerin yapısı. Çev. N. Kuyaş. İstanbul: Kırmızı Yayınları.

Nayır, F. ve Taşkın, P. (2017). Eğitim örgütlerinde örgütsel destek algısı ile inisiyatif alma davranışı arasındaki ilişki. Yüzüncü Yıl Üniversitesi Ĕgitim Fakültesi Dergisi, 14(1), 319-1356.

Overman, E. S. (1996). The new sciences of administration: Chaos and quantum theory. Public Administration Review, 56(5), 487-491.

Papatya, G. ve Dulupçu, M. A. (2006). Thinking quantum leadership for true transformation: The talisman of "not to know" at the threshold of new leadership. Ekonomi ve Yönetim Bilimleri Fakültesi. http://www.opf.slu.cz/vvr/akce/turecko/pdf/Papat ya.pdf adresinden 09.07.2018 tarihinde erişilmiştir.

Redfern, S., Coster, S., Evans, A., \& Dewe, P. (2010). An exploration of personal Initiative theory in the role of consultant nurses. Journal of Research in Nursing, 15(5), 435-453.

Seymen, A. F. (2017). Y ve Z kuşak insanı özelliklerinin Milli Eğitim Bakanlığı 2014-2019 stratejik programı ve TÜBİTAK Vizyon 2023 öngörüleri ile ilişkilendirilmesi. Kent Akademisi, 10(32), 467489.

Shelton, C. K., \& Darling, J. R. (2001). The quantum skills model in management: a new paradigm to enhance effective leadership. Leadership \& Organization Development Journal, 22(6), 264-273.doi: https://doi.org/10.1108/01437730110403196

Speier, C., \& Frese, M. (1997). Generalized self-efficacy as a mediator and moderator between control and complexity at work and personal initiative: A longitudinal field study in East Germany. Human Performance, 10(2), 171-192.

Stodgdill, R. M. (1948). Personal factors associated with leadership: A survey of theliterature. Journal of Psychology, 25, 35-71.

Stodgdill, R. M. (1974). Handbook of leadership: A survey of theory and research. NewYork: Free Press.

Tabachnick, B. G., \& Fidell, L. S. (2013). Using multivariate statistics. Boston, Pearson.

Taşkın, S. (2016). Öğretmenlerin örgütsel destek ve örgütsel destek ve örgütsel özdeşleşme düzeyleri ile inisiyatif iklimi arasındaki ilişki. (Yayınlanmamış yüksek lisans tezi). Abant İzzet Baysal Üniversitesi, Bolu.

Turan, S. (2017). Okul yöneticilerinin kuantum liderlik davranışlarının örgütsel zekâ düzeyine etkisi (Zonguldak İli Örneği). (Yayınlanmamış doktora tezi). Hacettepe Üniversitesi, Ankara.

Uzunçarşıll, Ü., Toprak, M. ve Ersun, O. (2000). Şirket kültürü ve iş prensipleri. İstanbul: İstanbul Ticaret Odas1.

Weick, K. E. (1976). Educational organizations as losely coupled systems. Administrative Science Quartely. 21(1), 1-9.

Wheatley, M. J. (2006). Leadership and the new science: Discovering order in a Chaotic World. San Fransisco: Berret Koehler.

Zimmerman, J. (2006). Why Some Teachers Resist Change and What Principals Can Do About It. Nassp Bulletin, 90(3), 238-249.

Zohar, D. (2018). 21.Yüzyılda kuantum liderlik. İstanbul: Kitap yayınları. 
EK-1: Araştırma İzin Belgesi

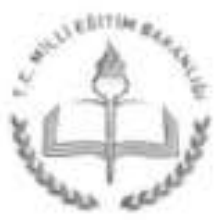

T.C.

ISTANBUL VAL ILIḠi

II Milli Eğitim Mưdürlūũú

Sayi : 59090411-20-E. 23707306

$10 / 12 / 2018$

Konu : Anket ve Araștirma jzin Talebi

\section{VALIILIK MAKAMINA}

Ilgi: a) Yuldaz Teknik Oniversitesinin 08.11 .2018 tarih ve 1811080287 sayll yazzs.

b) MEB. Yen. ve Eg. TK. Gn. Md. 22.08.2017 tarib ve 12607291/2017/25 No'lu Gen.

c) Milli Eğitim Arașturma ve Anket Komisyonunun 27,11.2018 tarihli tutanağ.

Yaldız Tekniik Oniversitesi Sosyal Bilimler Enstitusu yaksek lisans ogrencisi Meltem TUFAN' in "Okul Yöneticilerinin Kuantum Liderlik Davranışlarını, Öğretmenlerin Insiyatif Alma Düzeyine Etkisi" konulu tezi kapsamundn, ilimiz Kartal Ilçesinde bulunan ortaokullarda görev ögrettnenlere; anket uygulama isıemi hakkındaki ilgi (a) yazı ve ekleri Müdarlagümiñze incelenmiştir.

Araştırmacını söz konusu talebi; bilimsel amaç dıșuđa kullanılmaması, uygulama surasında bir örneği medtirlaggimízde muhafaza edilen mühürlü ve imzalı veri toplama araçlarını kurumlarmmı araştırmacı tarafından ulaştırılarak uygulanilması. katılımciların gōnülltülük esasıa göre seçilmesi, araşturma sonuç raporunun müdürlog̣ummüzden izin alımmadan kamuoyuyla paylaşılmaması koşuluyla, okul idarelerinin denetim, gözetim ve sorumluluğunda, eğitim-öğretimi aksatmayacak pekilde ilgi (b) Bakanlık emri esasları dảhilinde uygulanması, sonuçtan Mïdürlagũumüze rapor halinde (CD formatanda) bilgi verilmesi kaydıyla Moderlogumazce uygun görulmektedir.

Makamlarmızca đa uygun gồrülmesi balinde olurlarmıza arz ederim.

Ek:

Levent YAZICI

II Milli Eğitim Modoru

1- Genelge.

2- Komisyon Tutanaği.

OLUR

$10 / 12 / 2018$

Ahmet Handi USTA

Vali a.

Vali Yardimeisi 